\title{
Intensified paraglacial slope failures due to accelerating downwasting of a temperate glacier in Mt. Gongga, Southeastern Tibet Plateau
}

Yan Zhong ${ }^{1,2}$, Qiao Liu ${ }^{1}$, Matthew Westoby ${ }^{3}$, Yong Nie ${ }^{1}$, Francesca Pellicciotti ${ }^{4}$, Bo Zhang ${ }^{5}$, Jialun Cai ${ }^{5}$, Guoxiang Liu ${ }^{5}$, Haijun Liao ${ }^{1,2}$, Xuyang $\mathrm{Lu}^{1}$

$5 \quad{ }^{1}$ Institute of Mountain Hazards and Environment, Chinese Academy of Sciences, Chengdu 610041, China

${ }^{2}$ College of Resources and Environment, University of Chinese Academy of Sciences, Beijing 100049, China

${ }^{3}$ Department of Geography and Environmental Sciences, Engineering and Environment, Northumbria University, Newcastle upon Tyne NE1 8ST, UK

${ }^{4}$ Swiss Federal Institute for Forest, Snow and Landscape Research WSL, 8903 Birmensdorf, Switzerland

$10{ }^{5}$ Department of Surveying and Geo-Informatics, Faculty of Geosciences and Environmental Engineering, Southwest Jiaotong University, Chengdu 611756, China

Correspondence to: Qiao Liu (liuqiao@imde.ac.cn)

\begin{abstract}
Topographic development via paraglacial slope failure (PSF) represents a complex interplay between geological structure, climate, and glacial denudation. Where debris generated by PSFs is deposited on the surface of a glacier, this debris can increase the extent or thickness of a supraglacial debris-cover, in turn modifying glacier ablation and affecting meltwater generation. To date, little attention has been paid to intensity and frequency of PSFs in glacierised, monsoon temperate regions of Southeast Tibet. We mapped PSFs along the $5 \mathrm{~km}$-long, west-east trending ice tongue of Hailuogou Glacier (HLG), Mt. Gongga, using repeat satellite- and UAV-derived imagery between 1990 and 2020. Three types of PSF were identified: (A) rock fall, (B) sediment-mantled slopes slide and collapse, and (C) gully headwards erosion. We analyzed the formation, evolution and current state of these PSFs and discuss these aspects with relation to glacier dynamics and paraglacial geomorphological history. South-facing slopes (true left of HLG) showed more destabilization and higher PSF activity than north-facing slopes. We observed annual average rates of downslope sliding for type B PSFs of 1.6-2.6 $\pm 0.04 \mathrm{~cm} \mathrm{~d}^{-1}$, whereas the average upward denudation rate for type C PSFs was $0.7-3.39 \mathrm{~cm} \mathrm{~d}^{-1}$. We show that type A PSFs are non-ice-contact rock collapses that occur as a long-term paraglacial response following glacier downwasting and the exposure of steep rocky cliffs

25 and which could also be influenced by precipitation, freeze-thaw cycling, earthquakes or other factors. In contrast, type B and C PSFs are a more immediate response to recent glacier downwasting. We further argue that the accelerating downwasting of glacier are used as a preparatory or triggering factor, which could directly or indirectly cause the PSFs.
\end{abstract}

\section{Introduction}

The thinning and retreat of mountain glaciers exposes new, unstable landscapes which are susceptible to rapid geomorphological changes (i.e., with a high entropy). Sparsely vegetated or unvegetated drift-mantled slopes are particularly susceptible to be modified by gravitational, aeolian and fluvial processes and rapidly reworked by debris flows, rock 
https://doi.org/10.5194/esurf-2021-18

Preprint. Discussion started: 29 March 2021

(c) Author(s) 2021. CC BY 4.0 License.

avalanches and slope-wash (Ballantyne, 2003;Ballantyne, 2002;Deline et al., 2015a;Eichel et al., 2013). Glacier downwasting can destabilize slopes through undercutting and, simultaneously, the progressive loss of buttress exerted by ice loading on its adjacent slopes may result in rock stress-releases, scilicet "debuttressing", altering the state of stress that exists within the slope accordingly. Such slope failures initiate five possible modes of response: (1) large-scale catastrophic rock slides and rock avalanches (Kirkbride and Deline, 2018; Fischer et al., 2010); (2) ice-contact slope movements (McColl and Davies, 2013); and (3) periodic small-scale rock topples or rock falls (Cook et al., 2013); (4) and deep-seated gravitational creep (Deline et al., 2015b;Ballantyne et al., 2014), and (5) paraglacial debris cones and valley fills (Ballantyne, 2002). These five types of response provide a useful framework for examining the processes and geomorphological consequences of slope adjustment after deglaciation. These responses can be further divided into two types: rock slope failures and sediment slope failures, which are usually described collectively as paraglacial slope failures (PSFs). PSFs encompass failure of steep rock walls and lateral moraine slopes following glacier downwasting (Church and Ryder, 1972;Fickert and Grüninger, 2018) and are widely distributed in deglaciating or deglaciated landscapes. PSFs constitute a key mechanism for rapid degradation of recently glacial landscapes, as they contribute to the disaggregation of large portions of valley sides and the transformation from U-shaped to

45 V-shaped valleys. High-frequency, low-magnitude PSFs can transport a considerable volume of debris onto glacier surfaces (Smith et al., 2020), thereby facilitate the accumulation of the supraglacial moraine. Because thin debris covers enhance ablation, whilst thicker covers suppress it (Fyffe et al., 2020), debris supply dynamics ultimately affect the glacial ablation and meltwater production (Rowan et al., 2018). In addition, accompanied by relatively rare but occasional rain storm events, those unsorted debris are very likely transformed into debris flows and cascading geo-disasters that threaten downstream infrastructure, freshwater availability and the safety of residents and tourist (Hewitt et al., 2011;Reznichenko et al., 2012).

Monsoonal temperate glaciers in the Southeastern (SE) Tibetan Plateau have experienced higher rates of mass loss and ice thinning than other High Mountain Asia (HMA) glacierized regions in past decades (Neckel et al., 2017;Brun et al., 2017), with an average thinning rate of $-0.55 \pm 0.23 \mathrm{~m} \mathrm{a}^{-1}$ during 2000 to 2016 (Brun et al., 2017). The combination of a large amount of glacial meltwater and abundant precipitation during the summer monsoon makes SE Tibet one of the most susceptible regions for glacier-related geo-hazards, such as glacial debris flows, ice/snow avalanches, glacier-related landslides, and glacial lake outburst floods (Fan et al., 2019; Cheng et al., 2010;Xu et al., 2012). For example, more than half of the debris flows recorded in the Linzhi Area, SE Tibet can be sourced to a cryospheric trigger (Hu et al., 2011). Further, a total of four glacierrelated landslides (1990-2018, (Liu et al., 2010;He et al., 2008;Pan et al., 2012;Cao et al., 2019;Liu et al., 2018;Liu and Liu,

60 2010)), and twelve glacial lake outburst floods (1931-2014, (Liu et al., 2019b; Yao et al., 2014)) incidents have been recorded across the SE Tibetan Plateau. These hazards have caused severe economic losses and heavy casualties and have affected socioeconomic development. It is anticipated that accelerating glacial mass loss and permafrost degradation due to climate warming will continue to destabilize the paraglacial landscapes and thus increase the frequency of related hazards in the SE Tibet Plateau. 
Mt. Gongga is located on the southeastern edge of the Tibetan Plateau, in the geological transitional zone between the Plateau and the Sichuan Basin (Liu and Zhang, 2017). It is a large natural reserve with medium human disturbance and a relatively developed glacier tourism sector. According to the Second Glacier Inventory in China (Liu et al., 2015), there are 75 temperate glaciers in Mt. Gongga, of which five larger valley glaciers have a length $>10 \mathrm{~km}$, including Hailuogou Glacier, Mozigou

Glacier, Yanzigou Glacier and Nanmenguangou Glacier on the eastern slope, and Gongba Glacier on the western slope (Li et al., 2010). In recent decades, remarkable retreat and thinning of these glaciers has been widely reported (Liu et al., 2010; He et al., 2008;Pan et al., 2012;Cao et al., 2019;:iu et al., 2018;Liu and Liu, 2010) and catastrophic glacial-geomorphological processes or glacier-related hazards, such as glacial debris flows and landslides, occur frequently in the Mt. Gongga region (Xu et al., 2007; Cai et al., 2021). PSFs in these catchments are generally considered to occur on steep rocky terrain and manifest

75 as mixed ice/snow/rock avalanche and rockfall originating from surrounding walls and triggered by frost weathering processes. Most glaciers on Mt. Gongga have a considerable surface debris cover in their ablation zones and are bordered by unconsolidated lateral-terminal moraines in the periglacial zones.

In this study we carried out investigations on the PSFs processes of Hailuogou Glacier (HLG) a typical temperate glacier

80 located on the east slope of Mt. Gongga. Our investigations are based on the analysis of satellite imagery and the field imagery acquired from an unpiloted aerial vehicle (UAV), combined with on-site geomorphological observations and measurements. The objectives of this research are to:

A. map and quantify slope failures and topographic change around Hailougou Glacier through time series image comparison;

B. describe and discuss the spatial distribution, spatiotemporal evolution, and possible forcing mechanism of different types of PSFs;

C. discuss the geomorphic and environmental effects of these slope processes, and further discuss possible linkages between PSFs, climate change, and glacier downwasting.

\section{Study area}

Hailuogou Glacier $\left(29^{\circ} 58.4^{\prime} \mathrm{N}, 101^{\circ} 91.6^{\prime} \mathrm{E}\right)$ is one of the largest debris-covered valley glaciers in the Mt. Gongga region (Fig.

90 1). It is a $\sim 13 \mathrm{~km}$-long, east-facing monsoon temperate glacier, has an area of $24.7 \mathrm{~km}^{2}$, and extends in altitude from $2990 \mathrm{~m}$ to $7556 \mathrm{~m}$ a.s.1. The glacier is $\sim 300-500 \mathrm{~m}$ in width, and the wider valley is deeply incised below the accumulation area (where the glacier broadens to $\sim 6 \mathrm{~km}$ in width). The upper section of the ice tongue (below the icefall) has a surface gradient of $\sim 10^{\circ}$ and is connected to very steep $\left(\sim 55^{\circ}\right)$ lateral slopes on both sides. At a distance of $\sim 1.5 \mathrm{~km}$ from the base of the icefall (middle section of the ice tongue), the glacier surface steepens to $\sim 12^{\circ}$ and becomes highly crevassed. At a distance of $2 \mathrm{~km}$ the glacier

95 turns its flow direction toward the north-east, and maintains a surface gradient of $\sim 13^{\circ}$ for the remaining $3 \mathrm{~km}$ (lower section of the ice tongue) stretching to the Little Ice Age (LIA) end-moraine. Paralleling with the lower section of the ice tongue, the 
height of lateral moraines to the current glacier surface is about $165 \mathrm{~m}$, which is comparable higher than the further upper glacier ( $\sim 86 \mathrm{~m}$ at the middle section of ice tongue).

100 The terminus of HLG has retreated more than $2 \mathrm{~km}$ since the LIA (Su and Shi, 2002) and this retreat has accelerated from 12.7 $\mathrm{m} \mathrm{a}^{-1}$ between 1966-1989 to $27.4 \mathrm{~m} \mathrm{a}^{-1}$ between 1998-2008. Between 1966 and 2009, mean ice surface elevation of its lower tongue had lowered at a rate of $1.1 \pm 0.4 \mathrm{~m} \mathrm{a}^{-1}$. Due to a suitable local thermal (warm) and moisture (wet) climatic conditions, vegetation is able to quickly establish itself on the exposed periglacial bare ground in glacier forelands and lateral moraine slopes, and even on some supraglacial debris-covered areas that are largely stagnant. The LIA preglacial zone (2980-2800 m)

105 is characterized by extremely fast primary vegetation succession, and hosts an integrated community ranging from coldadapted herbaceous species to Abies fabri (conifer pine) forest. Abies fabri forest patches are also seen along both lateral sides of the ice tongue on accumulated lateral moraine, which has been relative stable since the LIA.

Due to its low altitude, easy accessibility and adjacency to the forests and hot springs, HLG and its surrounding areas have been exploited for tourism since 1987. A glacier ropeway connects the two lateral moraines and transports visitors across the lower part of the ice tongue and provides access to a viewpoint on the southern side of the valley (S2 on Fig. 1) from where the ice tongue can be overlooked and accessed via trail. Between 2000 and 2011, the number of annual visitors increased from 44,000 to 384,000 (Zhu, 2015), and in 2019 the number reached 2,852,600 (Haiguanju, 2020). The increasing popularity of the glacier comes at a time when tourism facilities and infrastructure are becoming frequently disturbed due to paraglacial

115 landsliding, debris flows and flash floods. Beyond the objectives outlined above, there is a need to more fully understand the nature of slope failures in the vicinity so that these failures might be better anticipated and their potential impacts mitigated where possible.

\section{Data and methods}

\subsection{Paraglacial slope failures (PSFs) mapping}

120 Since the lower part of the HLG tongue and its adjacent slopes are located below the local tree line, any newly developed PSFs could be readily recognized from the changed exposed bare ground area (EBGA). To map the extents of PSFs, firstly we extracted the paraglacial EBGA by classifying the land surface with vegetated and unvegetated areas using the Normalized Difference Vegetation Index (NDVI), which was calculated using reflected red and near-infrared band values of satellite images. The PSFs were then extracted by excluding the areas covered by the glacier extents. A total of 8 satellite images

125 between 1990 and 2020 (Table 1), including Sentinel-2 (10m), RapidEye (5m), PlanetScope (PL, 3m), were used to extract the PSFs. These data constitute a multi-temporal and dynamic observation of HLG and its surrounding paraglacial environments. Due to the strong influence of the monsoon, the HLG is often covered with thick clouds in summer, rendering $75 \%$ of the available summer satellite images unusable. However, we successfully screened and synthesized several Landsat 
https://doi.org/10.5194/esurf-2021-18

Preprint. Discussion started: 29 March 2021

(c) Author(s) 2021. CC BY 4.0 License.

or Sentinel-2 cloudless images in 1990, 2000, 2016 and 2018 using the Google Earth Engine platform. NDVI can eliminate a part of the effect of hill-shade caused by the low angle of the sun on ground recognition. Therefore, we can used cloudless images of multiple seasons (spring, autumn and summer) to realize automatic extraction of PSFs boundaries. Of the seasonal data, the PSF boundaries extracted from images acquired in the northern hemisphere summer are generally less suffered from the terrain shadow than other seasons and can be used directly after validation, and the boundaries extracted from other seasons need to be manually corrected partly.

To enable more detailed mapping of recent PSF extents, UAV sorties were flown on 31 August 2016, 07 June 2017, and 15 May 2019 using a DJI Phanton 4 Pro UAV, 19 August 2018 using a DJI Phanton 4 RTK UAV which combination of a global navigation satellite system (GNSS) with a mean quality of $0.01 \mathrm{~m}+1 \mathrm{ppm}$ (RMS) in XY, and input photographs were stitched using Structure from Motion (SfM) software ContextCapture Center Master to create a time series of orthomosaic aerial images at $0.1 \mathrm{~m}$ resolution. In the first instance, UAV surveys were designed for capturing imagery of on- rather than off-glacier terrain (i.e., section 3.2). This design aspect of the UAV surveys, combined with topographic constraints on the UAV flight area, meant that not all ice-marginal slopes were successfully mapped (Fig. S1). All UAV images are co-registered and orthorectified using PL images acquired on 16 August 2018 and a 12.5m ALOS PALSAR DEM as control data. The optical-band PL image and PALSAR DEM hills-shade data were found to be well co-registered with each other through manual comparison of local topography (e.g., ridges and vertexes) from the peak of Mt. Gongga (7556 m a.s.l.) to the trimlines of the glacier close to its terminus ( $\sim 3000 \mathrm{~m}$ a.s.1.). To extract ground control points with which to georegister the UAV data, a total number of 54 features (Fig. S1) were selected on stable ground surfaces (e.g., exposed bed rock, trees and some buildings) around the ice tongue on the PL image and their corresponding altitudes were then extracted from the ALOS DEM. Finally, the quality of the successfully occupied positions was satisfactory (mean quality of $0.15 \mathrm{~m}$ in XY). Our workflow is summarized in Fig. 2.

\subsection{Glacier dynamics observations}

Many scholars have done detailed research on the area changes of the HLG over the past years (Li et al., 2010;He et al., 2008; Liu et al., 2018; Zhang et al., 2010; Liu et al., 2010). Zhang et al. (2010) reported a mean surface lowering rate of $1.1 \pm 0.4 \mathrm{~m}$ $\mathrm{a}^{-1}$ between 1966 and 2009 for the lower part of HLG ice tongue. Using hydrological balance approach, Liu et al. (2010) estimated a thinning rate of $0.5 \pm 0.4$ to $0.7 \pm 0.4 \mathrm{~m} \mathrm{a}^{-1}$ (1994-2004) for the whole HLG area. A more recent investigation by Cao et al. (2019) updated the period to 2015 and gave an overall mean ice surface lowing rate of $0.54 \pm 0.04 \mathrm{~m} \mathrm{a}^{-1}$ for all glaciers in Mt. Gongga. In this study, we compile above results and extended it to 2016 following Brun et al. (2017), who published a regional dataset of glacier surface elevation changes for the High Mountain Asia derived by differencing ASTER DEMs between 2000 and 2016. We employed the TopoDEM (1966), the Shuttle Radar Topography Mission (SRTM) 30m DEM (2000) and the ASTER-DEM difference between 2000 and 2016 to analyze the surface elevation changes of HLG between

1601966 and 2016. Surface elevation changes along five profile-lines in longitudinal (A-A') and transverse (B-B', C-C', D-D' and E-E') on the lower part of HLG (Fig. 1) were examined and compared. The four transverse lines were examined 
https://doi.org/10.5194/esurf-2021-18

Preprint. Discussion started: 29 March 2021

(c) Author(s) 2021. CC BY 4.0 License.

(c) (i)

approximately along the three types of PSFs (definition below). Glacier terminus retreat history was extended to 2019 using satellite images used in this study (Fig. 1).

165 For ice flow dynamics, the earliest observations of surface velocity of the HLG were during 1982-1991 field expeditions, during which the location changes of several stakes along the ice tongue were repeatedly measured. Unfortunately, the original coordinates data of those measurement (e.g., the precise geographic locations of the stakes) was not offered and results are published only as a velocity isoline map with point velocity value indicated. Zhang et al. (2010) has reported a multi-decadal slowdown of the HLG ice tongue between 1980s, 1990 and 2008, when an updated stake-based ice velocity was conducted during the 2008 summer. Using 38 SAR images acquired by PALSAR-1/2 satellites from 2007 to 2018, Liu et al. (2019a) extracted annual surface displacement velocities of the HLG between 2007 and 2018. Here we compared the long-term ice flow velocity changes of the HLG (also checked along the five profile-lines mentioned above), based on three-periods results of 1982-1983 (in situ observed), 2007-2011 and 2014-2018 (SAR satellite derived).

\subsection{Slope movement and outline change rate}

175 To quantify the surface displacement speed of slopes, we used QGIS software to identify between 20-40 tie points on a series of slopes (B1-B4 in Fig. 6, Fig. S2). We manually tracked the displacement of each point and calculated the mean horizontal displacement. In some cases, the displacement of the slope itself is unapparent or extremely low, but these same slopes have detectable headscarp erosion. To quantify rates of headscarp erosion, we used the PSF boundaries outlined by five highresolution remote sensing images from 2002 to 2019 (Google Earth SPOT-5 imagery for 2002, RapidEye images for 2011, 2014 and 2015, and PlanetScope image for 2019) to calculate an mean distance and annual retreat rate for these headscarps.

\subsection{Meteorological data}

The daily air temperature and precipitation data (1988/01/01--2018/12/31) used in this study were sourced from the Subalpine Ecosystem Observation Station (3000 m a.s.1., $2 \mathrm{~km}$ from glacier terminus), and provided by the Gongga Alpine Ecosystem Observation and Experiment Station (Gongga Mt. Station), Chinese Ecological Research Network (CERN;

185 http://www.cern.ac.cn/). During the period 1988-2018, the observed mean annual temperature at $3000 \mathrm{~m}$ a.s.l. was $4.5^{\circ} \mathrm{C}$. Rain gauges recorded an annual average of 314 days with precipitation with a mean annual amount of $1912 \mathrm{~mm}$ at $3000 \mathrm{~m}$ a.s.l., of which $88 \%$ was concentrated in the ablation seasons (April to October) and $\sim 42 \%$ was concentrated in summer months (July to September). 


\section{Results}

\subsection{Retreating, thinning and deceleration of the Hailuogou Glacier}

Glacier outlines in 2002, 2016 and 2019 (Fig. 1c) were manually delineated based on high resolution images (Google Earth SPOT-5 imagery for 2002, and UAV images for 2016 and 2019). Comparison of these outlines shows that the glacier tongue area has reduced from $2.30 \mathrm{~km}^{2}$ to $2.06 \mathrm{~km}^{2}$ (average $0.08 \mathrm{~km}^{2} \mathrm{a}^{-1}$ ) between 2016 and 2019 compared with the period 2002 2016, when it reduced from $2.65 \mathrm{~km}^{2}$ to $2.30 \mathrm{~km}^{2}$ (average $0.03 \mathrm{~km}^{2} \mathrm{a}^{-1}$ ). Between 2002 and 2016, the position of the glacier terminus showed a moderate retreat $\left(6 \mathrm{~m} \mathrm{a}^{-1}\right)$; whereas during the following three years (2016-2019), the terminus retreated more than $150 \mathrm{~m}\left(\sim 52 \mathrm{~m} \mathrm{a}^{-1}\right)$. Field observations indicate that the current glacier terminus area was no longer covered by a thicker debris cover as previous status and frequent collapse along the subglacial outlet channel became the major backwasting process causing the accelerated terminus retreat.

The lower part of the HLG tongue also showed continuous narrowing as it retreats due to ice thinning. Ice surface elevation and velocity along five profile lines (Fig. 3) show that the ice tongue has experienced substantial ice loss and slowdown over the past decades. The longitudinal line (A-A') along the glacial flow direction runs through the entire ablation zone. Between 1966 and 2000, we observed negligible to small changes in the surface elevation of the upper ice tongue $\left(-0.5 \sim 0 \mathrm{~m} \mathrm{a}^{-1}\right.$, between 3400 to $3700 \mathrm{~m}$ a.s.1), with a mean lowering rate of $-0.11 \mathrm{~m} \mathrm{a}^{-1}$. However, the ice tongue below $3200 \mathrm{~m}$ a.s.1 (3 4.5 km to the base of the icefall) thinned remarkably as the highest lowering rate up to $-2.2 \mathrm{~m} \mathrm{a}^{-1}$ near the glacier terminus. In contrast, the thinning rate of upper ice tongue has greatly increased between 2000 and 2016, with the surface elevation change rate remaining at around $-2.0 \mathrm{~m} \mathrm{a}^{-1}$. On the other hand, the lower part of ice tongue (below 3400m) shows a decreasing thinning rate towards the terminus. For transverse profiles B-B' and C-C', rates of surface elevation lowering were much higher during 2000-2016 (-1.8 $\left.\mathrm{m} \mathrm{a}^{-1}\right)$ than 1966-2000 (-0.3 0 $\left.\mathrm{m} \mathrm{a}^{-1}\right)$. In contrast, profiles D-D' and E-E' showed less surface lowering over the past 50 years, with thinning rates remaining around $-0.6 \mathrm{~m} \mathrm{a}^{-1}$ and $-0.9 \mathrm{~m} \mathrm{a}^{-1}$, respectively.

Analysis of ice surface velocities during three periods (1982-1983, 2007-2011, and 2014-2018) in the past 38 years (Fig. 3c) indicates that the lower ablation area of HLG has experienced gradual slowdown, with the rate of this deceleration decreasing upglacier (Fig. 3c, profile A-A') and with increasing proximity to the lateral margins (Fig. 3c, profiles B-E). Ice surface

215 velocities along all transverse cross sections has gradually decreased, with the greatest deceleration occurring along profiles B-B' to D-D' (mean rate of $0.26 \mathrm{~m} \mathrm{a}^{-1}$ ) and less along the E-E' section (mean rate of $0.06 \mathrm{~m}^{-1}$ ). Note that remarkable decelerations happened across the whole transverse profile of D-D' during our observation periods have led the ice tongue below almost stagnated (with velocity less than $0.1 \mathrm{~m} \mathrm{a}^{-1}$ ) during 2014-2018. 


\subsection{Paraglacial slope failures}

Mapped extents of the paraglacial collapsed areas between 1990 and 2020 were presented in Fig. 4. The extents of EBGA shows continual expansion during the observation period, with a total areal increase of $\sim 1 \mathrm{~km}^{2}$. The observed increase in the EBGA is approximately proportionate to the annual decrease in the GCA; the EBGA increases at a rate of $\sim 0.01 \mathrm{~km}^{2} \mathrm{a}^{-1}$ between 1990-2000, to $\sim 0.1 \mathrm{~km}^{2} \mathrm{a}^{-1}$ from 2019-2020. Due to the transient rock fall below the icefall from September to November 2018, the area increased significantly, with an expansion rate up to $9.94 \%$ within one year. In general, the northfacing slope (located on the true right side of the glacier) exhibits more stability, which manifests as a smaller EBGA and lower frequency of PSFs.

By combining visual analysis of our time-series remote sensing and UAV imagery with knowledge of slope material composition, erosion type, and event magnitude, we identified three typical styles of paraglacial slope failure that broadly with classifications proposed by Ballantyne (2002) and McColl (2012) (Fig. 5a):
A. rock fall
B. sediment-mantled slopes slide and collapse
C. gully headward erosion.

We present detailed case study analysis of each type of PSF observed at HLG below, and provide a summary of the dimensions and typology of specific PSFs identified in Fig. 5a in Table 2.

\subsubsection{Rock fall (PSF type A)}

Different magnitude rock falls are common at exposed steep bedrock terrain on both sides of HLG. Evidence of a recent single rock fall event (Type A, Fig. 5b) occurred around October 15, 2018 from a south-west facing slope at a distance of $\sim 0.3 \mathrm{~km}$ from the base of the icefall (Fig. 5b). The final deposit is $283 \mathrm{~m}$ in width, $200 \mathrm{~m}$ in length, $450 \mathrm{~m}$ in height from the glacier surface, covers a vertical height of $380 \mathrm{~m}$, slope length of $472 \mathrm{~m}$, and a $2 \mathrm{D}$ area of $\sim 47,000 \mathrm{~m}^{2}$. The runout length was approximately $365 \mathrm{~m}$ and the drop height $40 \mathrm{~m}$. The deposit corresponds to an estimated release volume of 60,000-100,000 $\mathrm{m}^{3}$ of light green granodiorite rock detached from $\sim 4000 \mathrm{~m}$ a.s.l. on a steep north-facing slope (Fig. $5 \mathrm{~b}$ ). The thickness of the deposit was estimated during a field visit to be $3-5 \mathrm{~m}$ and the volumetric estimate is based on the extent of the main detachment zone, and the deposit thickness and area (Fig. 5b). The failed rock block amalgamated additional material from below the main detachment zone and ran out on to the surface of HLG, resting supraglacially at around $3580 \mathrm{~m}$ a.s.l., demonstrating that is possible for sizeable volumes of rock fall to be delivered directly to the supraglacial environment in the glacier ablation zone, where it can contribute to debris layer thickening. The rockfall deposit and the existing glacier debris cover are slightly different 
https://doi.org/10.5194/esurf-2021-18

Preprint. Discussion started: 29 March 2021

(c) Author(s) 2021. CC BY 4.0 License.

in color and grain size and can thus can be some clearly delineated on the glacier surface, both in the field, and on remote sensing imagery.

We also observe other major rockfall scars on the lower part of the valley wall in close proximity to this scar-deposit (i.e., up to $260 \sim 400 \mathrm{~m}$ above the glacier surface; Fig. $5 \mathrm{~b}$ and 5c) suggesting that numerous smaller scale rock falls have occurred in this locality. Since the rock surface has been partially weathered and most of the bedrock has been covered by vegetation such as mosses and shrubs, we speculate that these rockfalls may have occurred earlier and are have not been documented by remote sensing images or literature. However, the vertical joints of exposed bedrock on both sides of the glacier are well developed, and small magnitude rockfalls occur more frequently (Fig. 5a, Fig. S3). Based on UAV images and field investigation, we found 15 small-magnitude rockfalls events on the paraglacial slopes, each with a mean area of $750 \mathrm{~m}^{2}$. The disintegrating rock mass was between 3100 and $3500 \mathrm{~m}$ a.s.l with the mean distance from the glacier surface is about $110 \mathrm{~m}$. These rockfalls of different magnitude have become one of the main ways for debris delivery to the glacier surface in HLG.

\subsubsection{Sediment-mantled slopes slide and collapse (PSF type B)}

We identified evidence of four major sediment-mantled slope slide and collapse (Type B, B1-B4, Fig. 5a). Combined, these features cover an area of 370,000 $\mathrm{m}^{2}$ (2019-PL) and are located on both north- and south-facing valley sides. The 2D area of

265 Type B PSFs steadily expanded over our monitoring period (Fig.4), with a total area increase of 297,000 $\mathrm{m}^{2}$ from 1990 to 2020 , and an areal expansion rate of $10.16 \% \mathrm{a}^{-1}$.

B1 (3500 m a.s.1, Fig. 6a) is located on a north-facing lateral moraine slope at a distance of $1.5 \mathrm{~km}$ from the base of the icefall, and is $114 \mathrm{~m}$ wide, $1035 \mathrm{~m}$ long, and 112,424 $\mathrm{m}^{2}$ in area. Between 2017 and 2019 the exposed area of this feature B1 slope increased by $12,125 \mathrm{~m}^{2}$, or a percentage increase of $12.09 \%$. A landslide with an area of $53,000 \mathrm{~m}^{2}$ is included as a nested feature within B1 (48.28\% of B1 area), and evidence of superimposed gullying is also found on the eastern, western, and northern segments of this feature. According to the conceptual model designed by Eichel et al. (2018), there are three stages which describe the transition from active to stable sediment-mantled slopes: (a) gullying, (b) solifluction, (c) stabilization. The B1 feature is typical of stage A, and is characterized by active gullying and evidence of debris flows, slope-wash, slope slides,

275 combining to produce a complex slope landform which hosts pioneer vegetation species and is very geomorphologically active. The UAV images in 2016 did not cover the B1 area completely, so we extracted 23 common tie points across UAV images from 2017 to 2019 to manually quantify the surface displacement rate; the slope showed downslope displacement of $1.96 \pm 0.04$ $\mathrm{cm} \mathrm{d}^{-1}$, and a maximum of $2.08 \pm 0.04 \mathrm{~cm} \mathrm{~d}^{-1}$ in the period 2017-2018.

280 Feature B2 (3150 m a.s.l, Fig. 6b) is the largest type B PSF and is located on the true left, south-facing moraine slope close to the glacier terminus (3240-3120 m a.s.l.). It is fan-shaped with a width of $\sim 262 \mathrm{~m}$, a length of $644 \mathrm{~m}$, a height of $\sim 120 \mathrm{~m}$ and a total area of $122,738 \mathrm{~m}^{2}$. In contrast to $\mathrm{B} 1$, this feature is characterized as a single landslide without any nested features (e.g. 
https://doi.org/10.5194/esurf-2021-18

Preprint. Discussion started: 29 March 2021

(c) Author(s) 2021. CC BY 4.0 License.

gullies). Analysis of satellite imagery shows that detectable slope movement began around the year 2000, which is consistent with the onset of accelerated lowering of the glacier surface in this region and accompanying debuttressing of ice-marginal topography. We selected 33 tie points evenly distributed in the B2 landslide area on the four-year UAV images (2016-2019) to monitor its surface displacement, which revealed that the landslide has fallen by an average of $2.63 \pm 0.04 \mathrm{~m} \mathrm{a}^{-1}$ in the UAV monitoring period, and the affected area has increased by $7,414 \mathrm{~m}^{2}$ via headscarp erosion. The highest rate of displacement was $4.32 \mathrm{~cm} \mathrm{~d}^{-1}$ and occurred between 2017-2018. Between 2011 and 2019, the collapsed area of B2 has expanded by 35,000 $\mathrm{m}^{2}$, with an expansion rate of $4.99 \% \mathrm{a}^{-1}$. The landslide has a vertical glide distance of $48 \mathrm{~m}$, and a horizontal displacement of 70 m. In the period 2017-2018 landslide activity forced closure of a zigzag trail path (Fig. 5e) which was used for accessing the glacier.

Across the valley from B2, we identify landslide B3 (3100 m a.s.l, Fig. 5f, Fig. 6c), which is $805 \mathrm{~m}$ in length, 132 in width, and $63,241 \mathrm{~m}^{2}$ in area and, like B2, is located on a lateral moraine close to the glacier terminus. The landslide has been effectively divided into five zones, delineated by four gullies (Fig. 5f). Analysis of satellite imagery show that the landslide began to develop around 2013, when a headscarp is first detectable. Feature tracking (33 tie points) analysis on repeat UAV images shows that the landslide has moved down with an average rate of $1.65 \pm 0.04 \mathrm{~cm} \mathrm{~d}^{-1}$ between 2016 and 2019 , with the highest rate of $1.97 \pm 0.04 \mathrm{~cm} \mathrm{~d}^{-1}$ occurring in the period 2017-2018.

300 Feature B4 (Fig. 6d) is also located on the north-facing (true right) lateral moraine slope of the glacier, approximately $3.5 \mathrm{~km}$ from the base of the icefall. It is $\sim 103 \mathrm{~m}$ in height, $993 \mathrm{~m}$ in length, and covers an area of $73,270 \mathrm{~m}^{2}$. Geomorphologically, this feature is the most complex of the type B PSFs, in that it represents a transition form that it exhibits landsliding behavior in two distinct zones at either end (covering an area of $18,244 \mathrm{~m}^{2}$, or $24.90 \%$ of the sediment-mantled moraine slope in this area) and also exhibits gully headward erosion (i.e., PSF Type C). Feature tracking analysis of 37 tie points indicates that the landslide moved downslope at an average rate of $1.66 \pm 0.04 \mathrm{~cm} \mathrm{~d}^{-1}$ between 2016 and 2019, with a maximum rate of $2.63 \pm 0.04$ $\mathrm{cm} \mathrm{d}^{-1}$ in 2017-2018.

\subsubsection{Gully headward erosion (PSF type C)}

The three major paraglacial gully headward erosion areas (C1-C3, Fig. 5a) are located at the intersections between three tributary streams which are fed by seasonally snowmelt and the main trunk of the HLG ice tongue. They have a total area of $324,000 \mathrm{~m}^{2}$ in 2019. The UAV images did not cover the entire areas of Type C slopes, therefore we used five PlanetScope, RapidEye, and Google Earth images from 2002, 2011-2019 to supplement these data and monitor development of these features (Fig. 7). Our mapping results show that the total area of these three gullies has expanded by $\sim 93,000 \mathrm{~m}^{2}$ between 2011 and 2019 , with an annual expansion rate of $5.02 \% \mathrm{a}^{-1}$. 
$315 \mathrm{C} 1$ is located on the northern slope of HLG at an altitude of $3200 \mathrm{~m}$ (Fig. 5g; Fig. 7a). In 2019 it had a length of $849 \mathrm{~m}$, a width of $312 \mathrm{~m}$ and an area of $139,135 \mathrm{~m}^{2}$. It is adjacent to a major tributary stream that drains the northern side of the valley and which intersects (and bisects) the true left lateral moraine where the glacier turns to flow eastward to its terminus. Field inspection of exposed surfaces at $\mathrm{C} 1$ reveal that it comprises a block of thick debris and sand deposits with some finer material, which was previously colonized by vegetation before being denuded by flowing water. In the period 2011-2015, the area of the gully expanded upslope at a rate of $10.44 \mathrm{~m} \mathrm{a}^{-1}$, and by 2019 the location of headward erosion was more clearly concentrated in the meltwater tributary channel (Fig. 7a). Between 2011 and 2019, the average upward denudation rate of the feature was $3.39 \mathrm{~cm} \mathrm{~d}^{-1}\left(12.20 \mathrm{~m} \mathrm{a}^{-1}\right)$ and the exposed area had increased by $45,449 \mathrm{~m}^{2}$, or $48.59 \%$ from 2011 (Tab. 2).

Gully C2 is situated on the southern slope (true right lateral moraine) of HLG at about $3200 \mathrm{~m}$ a.s.1 (Fig. 5h; Fig. 7b) and in 3252019 extended $\sim 160 \mathrm{~m}$ in width, $\sim 270 \mathrm{~m}$ in length, and $24,248 \mathrm{~m}^{2}$ in area. The exposed area of the gully expanded upslope along the path of a meltwater-fed tributary stream, with a gradient of $\sim 36^{\circ}$ close to the HLG moraine, and which originates from Hailuogou No. 3 Glacier ( $29^{\circ} 32.41^{\prime}$ N, $10158.05^{\prime}$ E). This tributary stream connects directly to the subglacial water system of HLG. The gully is most actively eroding upstream of the point at which it connects to HLG, with an average upward denudation rate of $0.76 \mathrm{~cm} \mathrm{~d}^{-1}$ between 2002 and 2019, producing an increase in sediment-covered area of 11,923 $\mathrm{m}^{2}$ in the same period.

Gully C3 is also located on the southern slope of HLG at $3500 \mathrm{~m}$ a.s.1 (Fig. 5i; Fig. 7c), around $\sim 800 \mathrm{~m}$ west of gully C2. The gully is formed by a tributary stream which is fed by meltwater from Hailuogou No. 2 Glacier (29 $32.82^{\prime}$ N, $101^{\circ} 56.92^{\prime}$ E), which became detached from HLG sometime after the 1930s (Liu and Zhang, 2017) and has since retreated to the edge of an ice scarped ridge. The gully is filled with glaciofluvially-transported glacial sediment and is deeply incised. Like C2, meltwater also flows into HLG glacier subglacially. Since 2002, expansion of the sediment-mantled area of this gully has occurred on the right (east) side of the gully and has recently begun to expand up along the left (west) bank of the channel. We expand the area of the gully to incorporate adjacent unvegetated lateral moraine, which also shows evidence of gullying and headward erosion. The total area of C3 increased by $14.3 \%$, from $109,500 \mathrm{~m}^{2}$ in 2002 to $160,474 \mathrm{~m}^{2}$ in 2019.

\section{Discussion}

\subsection{Possible forcing mechanism of different types of PSFs}

Many potential factors, include glacial history (mostly downwasting or debuttressing in HLG since Little Ice Age), rock structure (i.e., joint), seismicity and meteorological disturbances (i.e., precipitation, temperature and freeze-thaw cycling), have been generally considered as preconditioning, preparatory or triggering factors that combine to produce a PSF (McColl,

345 2012). In the discussion below we refer to these factors to discuss their relative importance in forcing the different types of PSF that we observe at Hailuogou Glacier. 
https://doi.org/10.5194/esurf-2021-18

Preprint. Discussion started: 29 March 2021

(c) Author(s) 2021. CC BY 4.0 License.

\subsubsection{Rock fall}

The 2018 rock fall (Fig. 5b) represents a rapid non-ice contact rock collapse adjacent to an area of the glacier which has experienced remarkable (80-100 m) thinning since it's Little Ice Age (LIA) maximum (Fig. 5c). More widely in the Mt. Gongga region, glacial and paraglacial landform assemblages display a strong influence of Late Pleistocene and Holocene glaciations, the most striking example of which are the deeply incised trunk and tributary valleys formed by higher rates of glacier erosion (Liu et al., 2009), glaciofluvial activity, and monsoonal precipitation; as such, paraglacial slopes are strongly modified by local glacial history, making this an important preconditioning and preparatory factor for rock fall. Anecdotally, small-scale rock collapses occur all year round on both sides of HLG (Fig. 5a; Fig. S3), especially from those rock slopes exhibiting vertical jointing. Our field investigations indicate that the main detachment zone of the 2018 rock fall has no faults but is highly jointed, which facilitates liquid water ingress and hydraulic erosion and is also conducive to promoting fracturing via freeze-thaw and ice segregation processes (Rodríguez-Rodríguez et al., 2018) which gradually loosens the rock block and might also be considered a trigger in causing blocks to eventually break away from the rock valley walls (Fischer et al., 2010).

Precipitation and temperature observations near the glacier were analyzed to better understand the role of key meteorological factors in causing the large rock fall in 2018 . The annual mean temperature was relatively low in $2018\left(4.5^{\circ} \mathrm{C}\right)$ compared to the preceding three years $\left(5.0^{\circ} \mathrm{C}\right.$, Fig. 9). Tab. 3 shows the number of days from 2014 to 2018 with different daily precipitation totals. We find that 2018 shows a slight precipitation intensity anomaly; the number of days with precipitation totals $<60 \mathrm{~mm}$ $\mathrm{d}^{-1}$ is broadly similar to the preceding four years, however, the daily maximum $(61 \mathrm{~mm}, 30$ June 2018) exceeded that of the previous four years. A prolonged monsoon, which lasted to the middle of October, was also observed in 2018, and only one day without precipitation was recorded in the 25 days between 14 September and 09 October (mean daily precipitation of $7.5 \mathrm{~mm}$ ) during which the rock fall occurred. Differences in the daily mean temperature between September to October 2018 and September to October 2014-2017 were relatively large (Fig. S4); the daily mean temperature was between 0.4 to $5.3^{\circ} \mathrm{C}$ from 01 to 09 October, 2018 compared to a range of $3.6-12.92^{\circ} \mathrm{C}$ for the preceding four years. From 20 to 29 September, the mean daily temperature (the observation on 30 September is missing) was similar to the preceding four years with a range of 6.6-13. $3^{\circ} \mathrm{C}$. The temperature lapse rate $\left(0.0065^{\circ} \mathrm{C} \mathrm{m}^{-1}\right.$ in humid air, (Hemond and Fechner, 2015)) have shown that when the temperature at the Gongga Mt. Station (3000 m a.s.l.) drops to about $6^{\circ} \mathrm{C}$, the temperature on the mountain at $4000 \mathrm{~m}$ a.s.l. approaches $0^{\circ} \mathrm{C}$ and begins to freeze. We therefore speculate that the abundant precipitation in the early days caused a large amount of liquid water ingress the rock fissure, then the frost heave caused the rock mass to eventually rupture (e.g. (Hartmeyer et al., 2020)). We finally suggest that abnormal precipitation and low temperature in 2018 may have acted as a preparatory factor and triggering factor for the observed rock fall, respectively.

Rock fall and other mass movements can be triggered by seismic activity, which can also act as a preparatory factor through its ability to cause rock damage (Huggel et al., 2007). The HLG region is seismically active, and in the last five year has 
https://doi.org/10.5194/esurf-2021-18

Preprint. Discussion started: 29 March 2021

(c) Author(s) 2021. CC BY 4.0 License.

(c) (i)

recorded 9 seismic events ranging from 2.9-3.8 in magnitude, all of which occurred in the period 2016-2017 (China Earthquake Administration, https://www.cea.gov.cn/). Although no significant seismic events were observed immediately prior to the 2018 rock fall, rock mass damage associated with historical seismic activity may have acted as a preparatory factor for the 2018 rock fall and other mass movements from deglaciated slopes in the wider catchment.

\subsubsection{Sediment-mantled slopes slide and collapse}

385 Type B PSFs are largely associated with lateral moraine instability and collapse. Elsewhere in the catchment we observe glacially smoothed and polished bedrock surfaces with steep inclination angles (a product of the geological, glacial, and climatic history of the catchment), and we infer that the failure of these unconsolidated slopes is caused by glacier downwasting and debuttressing (Cody et al., 2020), combined with a material angle of repose which is lower than the inclination of the underlying bedrock surface; sediment-mantled slopes hosting showing evidence of instability typically have a slope angle of

$39025^{\circ}$, whilst the inclination of exposed bedrock slopes close to the elevation of the present-day glacier surface is $45^{\circ}$. Whilst historically the glacier has essentially 'propped up' the lateral moraines, rapid reduction in the elevation of the glacier surface has directly contributed to slope instability, which is increasing in speed, corresponding to findings in van Woerkom et al. (2019).

395 The regional and local climate, which is characterized by abundant precipitation during the monsoon season, enables rapid succession of vegetation on deglaciated slopes. However, although this vegetation is extensive in its coverage, particularly on slopes immediately above the lateral moraines, it mostly comprises species with a shallow rooting depth which do not have a strong capacity to increase slope stability, especially at larger scales; shrub vegetation growing on the unstable B2 and B3 slopes is relatively young and does not mitigate deep translational failure, whereby unconsolidated sediment slides along the interface between the overlying moraine and steep underlying bedrock. We also observed that the displacement of all type B PSFs reached their maximum rate during the period 2017-2018, which may in part be related to increased air temperature (promoting enhanced glacier downwasting) and precipitation extremes in 2018.

\subsubsection{Gully headward erosion}

Glacier downwasting and meltwater from deglaciating tributary catchments enhance erosion of ice-marginal gullies and contribute to the expansion of actively eroding slopes in these landscapes; headward erosion of sidewall tributary gullies occurs as the local base level (i.e., the HLG glacier surface) falls (Williams and Koppes, 2020;Schiefer and Gilbert, 2007), and this effect is illustrated clearly at PSF C1 (Fig. 5g).

The upstream sediments were transported along the transport and accumulated to both sides of the glacier, with a fast erosion, for instance, the part with the largest change in area of $\mathrm{C} 1$ travels about $150 \mathrm{~m}$ in both horizontal and vertical directions. 
https://doi.org/10.5194/esurf-2021-18

Preprint. Discussion started: 29 March 2021

(c) Author(s) 2021. CC BY 4.0 License.

Therefore, we argue that surface fluvial erosion and glacier debuttressing simultaneously trigger the instability of the type C slopes (Dusik et al., 2019).

All the three major type $\mathrm{C}$ slopes are developed along the tributary streams, in which settings slope slides are usually limited but surface fluvial erosion plays the primary role. There should exist a seasonal plus of enhanced or uprush erosion rates, i.e., during the monsoon rainstorm seasons. However, we still could not track this process due to the lack of higher resolution observations in the current study. Nevertheless, it is suggested that this type of paraglacial adjustment is still in active process based on the current observed situation at both lateral sides of the Hailuogou Glacier. As the increase of the exposed area and the erosionable baseline, a period of accelerated sediment/debris flux to the surface or base of the glacier is expected in the following years.

\subsection{Relationships between climate, glacier evolution, local topography and PSF development}

Meteorological observations at nearby Gongga Mountain Station (Fig.1) show that the regional mean annual temperature has increased by about $1{ }^{\circ} \mathrm{C}$ (Fig. 9) over the past 30 years. We argue that accelerating downwasting of HLG in response to climatic warming serves as a preparatory or triggering factor for PSFs. Through the influence of temperature and precipitation, climatic factors can directly affect slope (in)stability (McColl, 2012;Coe, 2020) and on the other hand, it can indirectly affect the slope by promoting rock damage over repeated cycles of glacial advance and retreat (Grämiger et al., 2017), and, during periods of sustained negative mass balance (characterized by glacier downwasting and terminus retreat) through slope debuttressing and the failure of consolidated and unconsolidated slopes.

Despite a slowdown in recent decades (Fig. 3c), the flow velocity of Hailuogou Glacier is still higher than most mountain glaciers in Himalaya, Tian Shan and inner Tibet (Bhushan et al., 2018;Wang et al., 2016;Zhang et al., 2017;Ke et al., 2013). Previous work has quantified the evolution of the glacier's subglacial and englacial hydrology, and revealed a highly efficient hydrological system that is maintained in both summer and winter months (Liu and Liu, 2010); an abundance of meltwater and subglacial and englacial debris (which we infer because of the debris-covered nature of the glacier, e.g. (Miles et al., 2021))

435 act as effective "grinding tools" for glacial abrasion. The estimated erosion rate is 2.2-11.4 $\mathrm{mm} \mathrm{a}^{-1}$ which is consistent with other temperate glacier but higher than the continental glaciers $\left(0.1-1.0 \mathrm{~mm} \mathrm{a}^{-1}\right.$ )(Liu et al., 2009). A high erosion rate contributes to valley incision and the steepening of valley flanks, which increase in exposed area and angle and therefore likely to become more prone to instability.

440 South-facing slopes show more (and a greater range) of instabilities, both in terms of magnitude and frequency. This is particularly obvious compare the C-C', D-D' and E-E' profiles. It can be seen from profile D-D' in Fig. 3 a, b that the thinning rate of the glacier under the south-facing slope is much greater than that on the opposite side (ice thinning rate of difference was $1.5 \mathrm{~m} \mathrm{a}^{-1}$ ), which may be caused by the lower surface temperature due to the topographic shading on the glacier areas 
under the north-facing slope (Liao et al., 2020). Therefore, PSFs and glaciers downwasting show the same movement in temporal and spatial. This observed pattern further indicates that there is a direct connection between glacier downwasting and PSFs occurrence.

At the same time, a large number of debris fell into the glacier surface, increasing the range and thickness of the supraglacial debris-cover, which in turn affected the temperature and downwasting of the glacier and the climate. The relationship between the three can be shown in Fig. 8.

\subsection{Geomorphological and environmental implications}

Similar to other studies (Dunning et al., 2015;Glueer et al., 2020; Hedding et al., 2020) our analyses show a temporal and spatial component to PSF development following rapid deglaciation. Following many thousands of annual thermo-hydromechanical loading cycles, which promote rock damage (Grämiger et al., 2017;Glueer et al., 2020) the bedrock slopes bordering HLG are well-prepared for failure, and this response is beginning to manifest as specific triggering events occur and/or mechanical rock mass thresholds are crossed. Similarly, unconsolidated lateral moraines show signs of increasing deformation and translational movement in response to glacier downwasting and debuttressing; we hypothesize that this will continue until critical angles of repose are reached, which will be followed by vegetation colonization and advanced soil development (Eichel et al., 2018).

Earlier in this article, we posited that the buttressing effect of ice prevented slope movement, and that slope deformation that we observed were largely a response to debuttressing. In the case of lateral moraine evolution, this is likely to be true. However, it is feasible that, since ice is lower in density than rock, failing rock slopes may move into the glacier if the stress they exert exceeds the resistance provided by the glacier ice. This geomorphological phenomena has been identified in the Southern Alps of New Zealand (McColl and Davies, 2013), where mountain glaciers occupy equally steep valleys. Field evidence from the monitoring of the B2 slope by UAV images for four consecutive years (Fig 6b) indicates that the glacier in this vicinity has narrowed or squeezed. The direction of the glacier movement at the boundary with B2 changes as B2 advances, which causes the original arc of the glacier boundary to be destroyed. The greatest change in the location of the glacier boundary bordering slope B2 are during the period 2017-2018, which is consistent with the fastest displacement speed $\left(\sim 4.32 \mathrm{~cm} \mathrm{~d}^{-1}\right)$ of the slope during the wider monitoring campaign. Our results may imply that the weight of the moraine may be sufficient to deform the glacier ice, as hypothesized by McColl and Davies (2013).

Due to the warm and humid climate of the region, the LIA preglacial zone (2980-2800 m) of Hailuogou Glacier is characterized by a fast-primary ecological succession landscape, characterized by succession community from cold-adapted herbaceous to Abies fabri forest. Glacier downwasting and permafrost thaw have led to accelerated paraglacial erosion and increased 475 frequency of proglacial debris flow and flash flood, which has occasionally disturbed the established preglacial vegetation. Accumulated surface moraine debris near the lowest ice tongue has suppressed local ice ablation and promoted ice stagnation, 
and in some locations this stagnation has led to the establishment of supraglacial vegetation, although this colonization is typically ephemeral due to ice cliff backwasting, for example.

\section{Conclusion}

480 We used repeat UAV and satellite remote sensing imagery as the basis for identifying and analyzing the evolution of three styles of paraglacial slope failure at Hailougou Glacier between 1990 and 2020, and explore these results in the context of their potential driving mechanisms. Over this period the glacier terminus has retreated $\sim 150 \mathrm{~m}\left(5 \mathrm{~m} \mathrm{a}^{-1}\right)$, its surface has down-wasted by $-0.88 \mathrm{~m} \mathrm{a}^{-1}$, with thinning observed over $83.50 \%$ of the ablation zone study area, and the glacier velocity has slowed from a mean of $0.32 \mathrm{~m} \mathrm{~d}^{-1}$ (period 1982 to 1983) to $0.11 \mathrm{~m} \mathrm{~d}^{-1}$ (2014 to 2018). Rapid downwasting of the glacier surface has exposed oversteepened ice-marginal slope topography, which show evidence of widespread instability in the form of i) rock fall and debris avalanching from bedrock slopes, ii) collapse of unconsolidated lateral moraines, and iii) increased erosion activity in tributary valleys. South-facing valley slopes (true left of the glacier) exhibited more destabilization and higher PSF activity than north-facing (true right) valley slopes. Set against a background of frequent, small-scale rock falls that are anecdotally recorded in the area, a large rock fall occurred in Autumn 2018. Non-ice-contact rock falls in deglaciating catchments are a well-established, short- to long-term response of paraglacial slopes following glacier downwasting and rock slope exposure, however, analysis of antecedent meteorological conditions suggests that an abnormally long monsoon and low temperature may have served to prepare, and perhaps trigger this rock slope failure. Deformation of sediment-mantled moraine slopes (mean 1.6-2.6 $\pm 0.04 \mathrm{~cm} \mathrm{~d}^{-1}$ ) and an increase in erosion activity in ice-marginal tributary valleys caused by a drop in local base level (gully headward erosion rate $=0.7-3.39 \mathrm{~cm} \mathrm{~d}^{-1}$ ) have occurred in tandem with recent glacier downwasting. Field evidence indicates that the glacier ice body adjacent to unstable rock and sediment-mantled slopes has narrowed, or 'squeezed', and we hypothesize that this may be the result of ice deformation caused by ice-marginal slope displacement and loading, but which requires further field investigation. Longer-term monitoring will provide a clearer picture of the feedbacks between (accelerating) glacier downwasting, climatic conditions, and paraglacial landscape response in this data-poor region.

\section{Data availability}

500 The paraglacial slope failure shape files can be requested by email from the author zhongyan19@mails.ucas.ac.cn

\section{Author contributions}

QL and XL initiated the underlying research project and obtained the funding. QL developed the research goal and designed the study. QL, YN, BZ, JC, HL and GL performed the primary UAV data. QL and YZ conducted and analyzed the data. YZ, QL, MW, YN and FP wrote the paper. 
https://doi.org/10.5194/esurf-2021-18

Preprint. Discussion started: 29 March 2021

(c) Author(s) 2021. CC BY 4.0 License.

\section{Competing interests}

The authors declare that they have no conflict of interest.

\section{Acknowledgements}

This work was funded by the NSFC Project (41871069) and the Sichuan Science and Technology Programs (2021JDJQ0009, 2020JDJQ0002). The authors gratefully acknowledge the PlanetLab for provision of PlanetScope and RapidEye imagery, and

U.S. Geological Survey for Landsat satellite images. MW and FP acknowledge funding from Royal Society-Newton Fund project 'Understanding glacier and hydrological changes in the Tibetan Plateau using high-resolution monitoring and modelling'.

\section{References}

Ballantyne, C.: Paraglacial landsystems, Glacial Landsystems. Arnold, London, 432, 461, 2003.

515 Ballantyne, C. K.: Paraglacial geomorphology, Quaternary Science Reviews, 21, 1935-2017, doi:10.1016/S02773791(02)00005-7, 2002.

Ballantyne, C. K., Wilson, P., Gheorghiu, D., and Rodés, À.: Enhanced rock-slope failure following ice-sheet deglaciation: timing and causes, earth surface processes and landforms, 39, 900-913, doi:10.1002/ESP.3495, 2014.

Bhushan, S., Syed, T. H., Arendt, A. A., Kulkarni, A. V., and Sinha, D.: Assessing controls on mass budget and surface velocity variations of glaciers in Western Himalaya, Scientific Reports, 8, 8885, doi:10.1038/s41598-018-27014-y, 2018.

Brun, F., Berthier, E., Wagnon, P., Kääb, A., and Treichler, D.: A spatially resolved estimate of High Mountain Asia glacier mass balances from 2000 to 2016, Nature Geoscience, 10, 668-673, doi:10.1038/ngeo2999, 2017.

Cai, J., Jia, H., Liu, G., Zhang, B., Liu, Q., Fu, Y., Wang, X., and Zhang, R.: An Accurate Geocoding Method for GB-SAR Images Based on Solution Space Search and Its Application in Landslide Monitoring, Remote Sensing, 13, 832, 525 doi:10.3390/rs13050832, 2021.

Cao, B., Pan, B., Guan, W., Wen, Z., and Wang, J.: Changes in glacier volume on Mt. Gongga, southeastern Tibetan Plateau, based on the analysis of multi-temporal DEMs from 1966 to 2015, Journal of Glaciology, 65, 366-375, 2019.

Cheng, Z. L., Liu, J. J., and Liu, J. K.: Debris flow induced by glacial lake break in southeast Tibet, wit transactions on engineering sciences, 67, 101-111, doi:10.2495/DEB100091, 2010.

530 Church, M., and Ryder, J. M.: Paraglacial Sedimentation: A Consideration of Fluvial Processes Conditioned by Glaciation, GSA Bulletin, 83, 3059-3072, doi:10.1130/0016-7606(1972)83[3059:psacof]2.0.co;2, 1972.

Cody, E., Anderson, B. M., McColl, S. T., Fuller, I. C., and Purdie, H. L.: Paraglacial adjustment of sediment slopes during and immediately after glacial debuttressing, Geomorphology, 371, 107411, doi:10.1016/j.geomorph.2020.107411, 2020. 
https://doi.org/10.5194/esurf-2021-18

Preprint. Discussion started: 29 March 2021

(c) Author(s) 2021. CC BY 4.0 License.

Coe, J. A.: Bellwether sites for evaluating changes in landslide frequency and magnitude in cryospheric mountainous terrain:

a call for systematic, long-term observations to decipher the impact of climate change, Landslides, 17, 2483-2501, doi:10.1007/s10346-020-01462-y, 2020.

Cook, S. J., Porter, P. R., and Bendall, C. A.: Geomorphological consequences of a glacier advance across a paraglacial rock avalanche deposit, Geomorphology, 189, 109-120, doi:10.1016/j.geomorph.2013.01.022, 2013.

Deline, P., Gruber, S., Delaloye, R., Fischer, L., Geertsema, M., Giardino, M., Hasler, A., Kirkbride, M., Krautblatter, M., and

540 Magnin, F.: Ice loss and slope stability in high-mountain regions, in: Snow and Ice-related hazards, risks and disasters, Elsevier, 521-561, 2015a.

Deline, P., Hewitt, K., Reznichenko, N., and Shugar, D.: Chapter 9 - Rock Avalanches onto Glaciers, in: Landslide Hazards, Risks and Disasters, edited by: Shroder, J. F., and Davies, T., Academic Press, Boston, 263-319, 2015b.

Dunning, S. A., Rosser, N. J., McColl, S. T., and Reznichenko, N. V.: Rapid sequestration of rock avalanche deposits within glaciers, Nat Commun, 6, 7964, doi:10.1038/ncomms8964, 2015.

Dusik, J.-M., Neugirg, F., and Haas, F.: Slope Wash, Gully Erosion and Debris Flows on Lateral Moraines in the Upper Kaunertal, Austria, in: Geomorphology of Proglacial Systems: Landform and Sediment Dynamics in Recently Deglaciated Alpine Landscapes, edited by: Heckmann, T., and Morche, D., Springer International Publishing, Cham, 177-196, 2019.

Eichel, J., Krautblatter, M., Schmidtlein, S., and Dikau, R.: Biogeomorphic interactions in the Turtmann glacier forefield,

Switzerland, Geomorphology, 201, 98-110, doi:10.1016/j.geomorph.2013.06.012, 2013.

Eichel, J., Draebing, D., and Meyer, N.: From active to stable: Paraglacial transition of Alpine lateral moraine slopes, Land Degradation \& Development, 29, 4158-4172, doi:10.1002/ldr.3140, 2018.

Fan, J., An, C., Zhang, X., Li, X., and Tan, J.: Hazard assessment of glacial lake outburst floods in Southeast Tibet based on RS and GIS technologies, International Journal of Remote Sensing, 40, 4955-4979, doi:10.1080/01431161.2019.1577578, 5552019.

Fickert, T., and Grüninger, F.: High-speed colonization of bare ground-Permanent plot studies on primary succession of plants in recently deglaciated glacier forelands, Land Degradation \& Development, 29, 2668-2680, doi:10.1002/ldr.3063, 2018. Fischer, L., Amann, F., Moore, J. R., and Huggel, C.: Assessment of periglacial slope stability for the 1988 Tschierva rock avalanche (Piz Morteratsch, Switzerland), Engineering Geology, 116, 32-43, doi:10.1016/j.enggeo.2010.07.005, 2010.

560 Fyffe, C. L., Woodget, A. S., Kirkbride, M. P., Deline, P., Westoby, M. J., and Brock, B. W.: Processes at the margins of supraglacial debris cover: Quantifying dirty ice ablation and debris redistribution, Earth Surface Processes and Landforms, 45, 2272-2290, doi:10.1002/esp.4879, 2020.

Glueer, F., Loew, S., and Manconi, A.: Paraglacial history and structure of the Moosfluh Landslide (1850-2016), Switzerland, Geomorphology, 355, 106677, doi:10.1016/j.geomorph.2019.02.021, 2020.

565 Grämiger, L. M., Moore, J. R., Gischig, V. S., Ivy-Ochs, S., and Loew, S.: Beyond debuttressing: Mechanics of paraglacial rock slope damage during repeat glacial cycles, Journal of Geophysical Research: Earth Surface, 122, 1004-1036, doi:10.1002/2016JF003967, 2017. 
https://doi.org/10.5194/esurf-2021-18

Preprint. Discussion started: 29 March 2021

(c) Author(s) 2021. CC BY 4.0 License.

Haiguanju: Hailuogou Scenic Area achieved another record in tourist reception in 2019, http://www.gzz.gov.cn/gzzrmzf/c100044/202001/38048f67a8d3431fa8fe98d250b42281.shtml, 2020.

Hartmeyer, I., Delleske, R., Keuschnig, M., Krautblatter, M., Lang, A., Schrott, L., and Otto, J. C.: Current glacier recession causes significant rockfall increase: the immediate paraglacial response of deglaciating cirque walls, Earth Surf. Dynam., 8 , 729-751, doi:10.5194/esurf-8-729-2020, 2020.

He, Y., Li, Z., Yang, X., Jia, W., He, X., Song, B., Zhang, N., and Liu, Q.: Changes of the Hailuogou Glacier, Mt. Gongga, China, against the background of global warming in the last several decades, Journal of China University of Geosciences, 19 , 271-281, 2008.

Hedding, D. W., Erofeev, A. A., Hansen, C. D., Khon, A. V., and Abbasov, Z. R.: Geomorphological processes and landforms of glacier forelands in the upper Aktru River basin (Gornyi Altai), Russia: evidence for rapid recent retreat and paraglacial adjustment, Journal of Mountain Science, 17, 824-837, doi:10.1007/s11629-019-5845-5, 2020.

Hemond, H. F., and Fechner, E. J.: Chapter 4 - The Atmosphere, in: Chemical Fate and Transport in the Environment (Third

Edition), edited by: Hemond, H. F., and Fechner, E. J., Academic Press, Boston, 311-454, 2015.

Hewitt, K., Clague, J., and Deline, P.: Catastrophic Rock Slope Failures and Mountain Glaciers, in: Encyclopedia of Snow, Ice and Glaciers, edited by: Singh, V, P., Singh, P, and Haritashya, Springer, pp. 113-126, 2011.

Hu, G., Chen, N., Deng, M., and Wang, Y.: Classification and Initiation Conditions of Debris Flows in Linzhi Area, Tibet, Bulletin of Soil and Water Conservation, 31, 193-197+221, 2011.

Huggel, C., Caplan-Auerbach, J., Waythomas, C. F., and Wessels, R. L.: Monitoring and modeling ice-rock avalanches from ice-capped volcanoes: A case study of frequent large avalanches on Iliamna Volcano, Alaska, Journal of Volcanology and Geothermal Research, 168, 114-136, doi:10.1016/j.jvolgeores.2007.08.009, 2007.

Ke, C.-Q., Kou, C., Ludwig, R., and Qin, X.: Glacier velocity measurements in the eastern Yigong Zangbo basin, Tibet, China, journal of glaciology, 59, 1060-1068, doi:10.3189/2013JOG12J234, 2013.

Kirkbride, M. P., and Deline, P.: Spatial heterogeneity in the paraglacial response to post-Little Ice Age deglaciation of four headwater cirques in the Western Alps, Land Degradation \& Development, 29, 3127-3140, doi:10.1002/ldr.2975, 2018.

Li, Z., He, Y., Yang, X., Theakstone, W. H., Jia, W., Pu, T., Liu, Q., He, X., Song, B., Zhang, N., Wang, S., and Du, J.: Changes of the Hailuogou glacier, Mt. Gongga, China, against the background of climate change during the Holocene, Quaternary International, 218, 166-175, doi:10.1016/j.quaint.2008.09.005, 2010.

Liao, H., Liu, Q., Zhong, Y., and Lu, X.: Landsat-Based Estimation of the Glacier Surface Temperature of Hailuogou Glacier, Southeastern Tibetan Plateau, Between 1990 and 2018, remote sensing, 12, doi:10.3390/RS12132105, 2020.

Liu, G., Chen, Y., Zhang, Y., and Fu, H.: Mineral deformation and subglacial processes on ice-bedrock interface of Hailuogou Glacier, Chinese Science Bulletin, 54, 3318-3325, doi:10.1007/s11434-009-0289-x, 2009.

Liu, G., Zhang, B., Liu, Q., Zhang, R., Cai, J., Fu, Y., Yu, B., and Li, Z.: Monitoring Dynamics of Hailuogou Glacier and the

600 Secondary Landslide Disasters Based on Combination of Satellite SAR and Ground-Based SAR, Geomatics and Information Science of Wuhan University, 44, 980-995, 2019a. 
https://doi.org/10.5194/esurf-2021-18

Preprint. Discussion started: 29 March 2021

(c) Author(s) 2021. CC BY 4.0 License.

Liu, J., Zhang, J., Gao, B., Li, Y., Mengyu, L., Wujin, D., and Zhou, L.: An overview of glacial lake outburst flood in Tibet, China, Journal of Glaciology and Geocryology, 41, 1335-1347, $2019 \mathrm{~b}$.

Liu, Q., and Liu, S.: Seasonal evolution of the englacial and subglacial drainage systems of a temperate glacier revealed by 605 hydrological analysis, Sci. Cold Arid. Reg, 2, 51-58, 2010.

Liu, Q., Liu, S., Zhang, Y., Wang, X., Zhang, Y., Guo, W., and Xu, J.: Recent shrinkage and hydrological response of Hailuogou glacier, a monsoon temperate glacier on the east slope of Mount Gongga, China, Journal of Glaciology, 56, 215$224,2010$.

Liu, Q., and Zhang, Y.: Studies on the dynamics of monsoonal temperate glaciers in Mt.Gongga: a review, Mountain Research, 35, 717-726, 2017.

Liu, Q., Liu, S., and Cao, W.: Seasonal Variation of Drainage System in the Lower Ablation Area of a Monsoonal Temperate Debris-Covered Glacier in Mt. Gongga, South-Eastern Tibet, Water, 10, 1050, 2018.

Liu, S., Yao, X., Guo, W., Xu, J., and Shangguan, D.: The contemporary glaciers in China based on the Second Chinese Glacier Inventory, Acta Geographica Sinica, 70, 3-16, 2015.

615 McColl, S. T.: Paraglacial rock-slope stability, Geomorphology, 153-154, 1-16, doi:10.1016/j.geomorph.2012.02.015, 2012. McColl, S. T., and Davies, T. R.: Large ice-contact slope movements: glacial buttressing, deformation and erosion, Earth Surface Processes and Landforms, 38, 1102-1115, 2013.

Miles, K. E., Hubbard, B., Miles, E. S., Quincey, D. J., Rowan, A. V., Kirkbride, M., and Hornsey, J.: Continuous borehole optical televiewing reveals variable englacial debris concentrations at Khumbu Glacier, Nepal, Communications Earth \& Environment, 2, 12, doi:10.1038/s43247-020-00070-x, 2021.

Neckel, N., Loibl, D., and Rankl, M.: Recent slowdown and thinning of debris-covered glaciers in south-eastern Tibet, Earth and Planetary Science Letters, 464, 95-102, doi:10.1016/j.eps1.2017.02.008, 2017.

Pan, B., Zhang, G., Wang, J., Cao, B., Geng, H., Zhang, C., and Ji, Y.: Glacier changes from 1966-2009 in the Gongga Mountains, on the south-eastern margin of the Qinghai-Tibetan Plateau and their climatic forcing, The Cryosphere, 6, 1087, 2012.

Reznichenko, N. V., Davies, T. R. H., Shulmeister, J., and Larsen, S. H.: A new technique for identifying rock avalanchesourced sediment in moraines and some paleoclimatic implications, Geology, 40, 319-322, doi:10.1130/g32684.1, 2012.

Rodríguez-Rodríguez, L., González-Lemos, S., Ballesteros, D., Valenzuela, P., Domínguez-Cuesta, M. J., Llana-Fúnez, S., and Jiménez-Sánchez, M.: Timing of paraglacial rock-slope failures and denudation signatures in the Cantabrian Mountains (North Iberian Peninsula), Land Degradation \& Development, 29, 3159-3173, doi:10.1002/ldr.3012, 2018.

Rowan, A. V., Quincey, D. J., Gibson, M. J., Glasser, N. F., Westoby, M. J., Irvine-Fynn, T. D. L., Porter, P. R., and Hambrey, M. J.: The sustainability of water resources in High Mountain Asia in the context of recent and future glacier change, Geological Society, London, Special Publications, 462, 189, doi:10.1144/SP462.12, 2018.

Schiefer, E., and Gilbert, R.: Reconstructing morphometric change in a proglacial landscape using historical aerial photography and automated DEM generation, Geomorphology, 88, 167-178, doi:10.1016/j.geomorph.2006.11.003, 2007. 
https://doi.org/10.5194/esurf-2021-18

Preprint. Discussion started: 29 March 2021

(c) Author(s) 2021. CC BY 4.0 License.

Smith, W. D., Dunning, S. A., Brough, S., Ross, N., and Telling, J.: GERALDINE (Google earth Engine supRaglAciaL Debris INput dEtector) - A new Tool for Identifying and Monitoring Supraglacial Landslide Inputs, Earth Surf. Dynam. Discuss., 2020, 1-21, doi:10.5194/esurf-2020-40, 2020.

$\mathrm{Su}, \mathrm{Z}$., and Shi, Y.: Response of monsoonal temperate glaciers to global warming since the Little Ice Age, Quaternary International, 97-98, 123-131, doi:10.1016/S1040-6182(02)00057-5, 2002.

van Woerkom, T., Steiner, J. F., Kraaijenbrink, P. D. A., Miles, E. S., and Immerzeel, W. W.: Sediment supply from lateral moraines to a debris-covered glacier in the Himalaya, Earth Surf. Dynam., 7, 411-427, doi:10.5194/esurf-7-411-2019, 2019.

Wang, P., Li, Z., Li, H., Wang, W., Wu, L., Zhang, H., Huai, B., and Wang, L.: Recent Evolution in Extent, Thickness, and Velocity of Haxilegen Glacier No. 51, Kuytun River Basin, Eastern Tianshan Mountains, arctic antarctic and alpine research, 48, 241-252, doi:10.1657/AAAR0014-079, 2016.

Williams, H. B., and Koppes, M. N.: A comparison of glacial and paraglacial denudation responses to rapid glacial retreat, Annals of Glaciology, 60, 151-164, doi:10.1017/aog.2020.1, 2020.

Xu, Q., Shang, Y., AschTheo, v., Wang, S., Zhang, Z., and Dong, X.: Observations from the large, rapid Yigong rock slide debris avalanche, southeast Tibet, canadian geotechnical journal, 49, 589-606, doi:10.1139/T2012-021, 2012.

$650 \mathrm{Xu}, \mathrm{X} ., \mathrm{Ma}, \mathrm{D} ., \mathrm{He}, \mathrm{D}$., and Huang, H.: Analysis on hydro-thermal combination of debris flow occurrence in Mt. Gongga region, Mountain Research, 431-437, 2007.

Yao, X., Liu, S., Sun, M., and Zhang, X.: Study on the glacial lake outburst flood events in Tibet since the 20th Century, Journal of Natural Resources, 29, 1377-1390, 2014.

Zhang, Y., Fujita, K., Liu, S., Liu, Q., and Wang, X.: Multi-decadal ice-velocity and elevation changes of a monsoonal maritime glacier: Hailuogou glacier, China, journal of glaciology, 56, 65-74, doi:10.3189/002214310791190884, 2010.

Zhang, Y., Fujita, K., Liu, S., Liu, Q., and Wang, X.: Multi-decadal ice-velocity and elevation changes of a monsoonal maritime glacier: Hailuogou glacier, China, Journal of Glaciology, 56, 65-74, doi:10.3189/002214310791190884, 2017.

Zhu, Z.: On Characteristics of Visitor Flow to Hailuogou Glacier Forest Park in Sichuan, Journal of Huizhou University, 35, 66-69+80, 2015. 

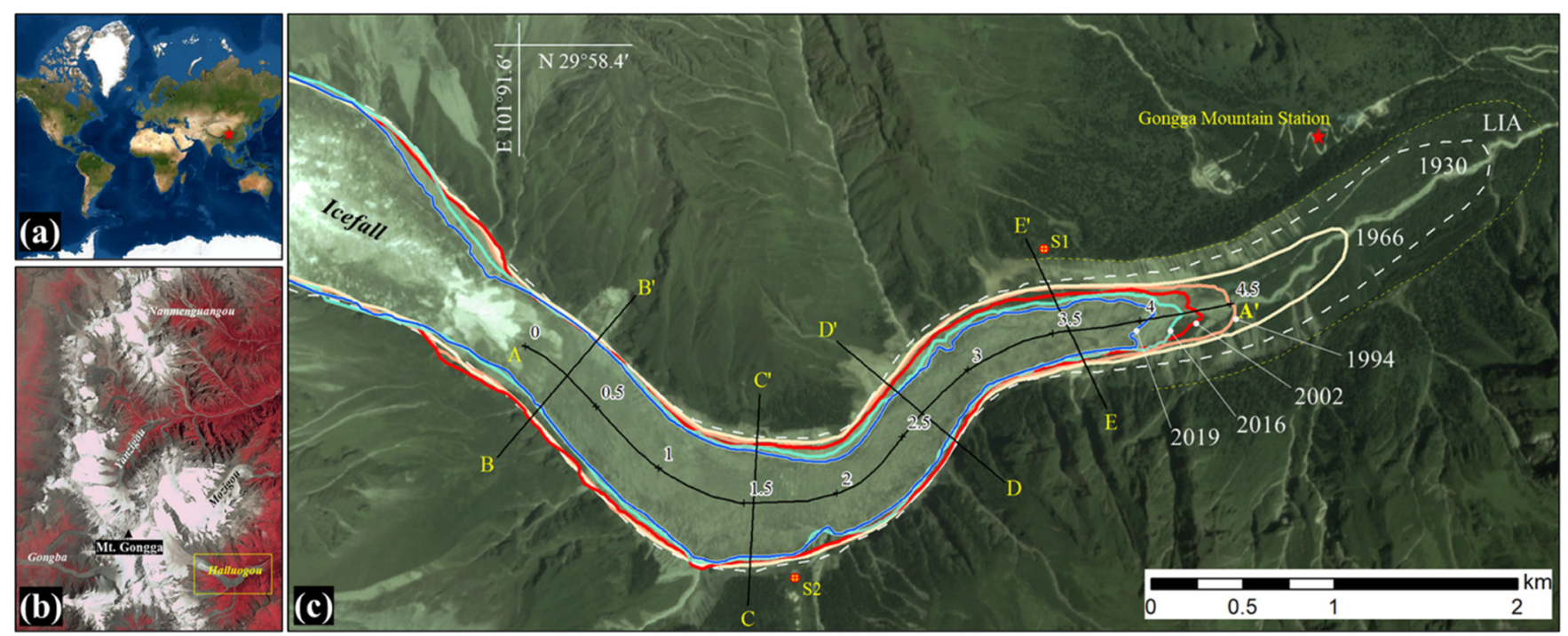

Figure 1: Map showing the location of Mt. Gongga (red star), the background image is from ESRI's world basemap (a), several large glaciers around the peak of Mt. Gongga based on Landsat image (b), and retreating history of HLG since the Little Ice Age based on PlanetScope image (c). S1 and S2 are tourist sightseen stands on both side of lateral moraines, and the red star indicates the location of Gongga Mountain Station. Longitudinal (A-A') and transverse (B-B', etc.) lines are set to examine the variation of flow velocities and surface elevations (Fig. 3) of the ice tongue. 
https://doi.org/10.5194/esurf-2021-18

Preprint. Discussion started: 29 March 2021

(c) Author(s) 2021. CC BY 4.0 License.

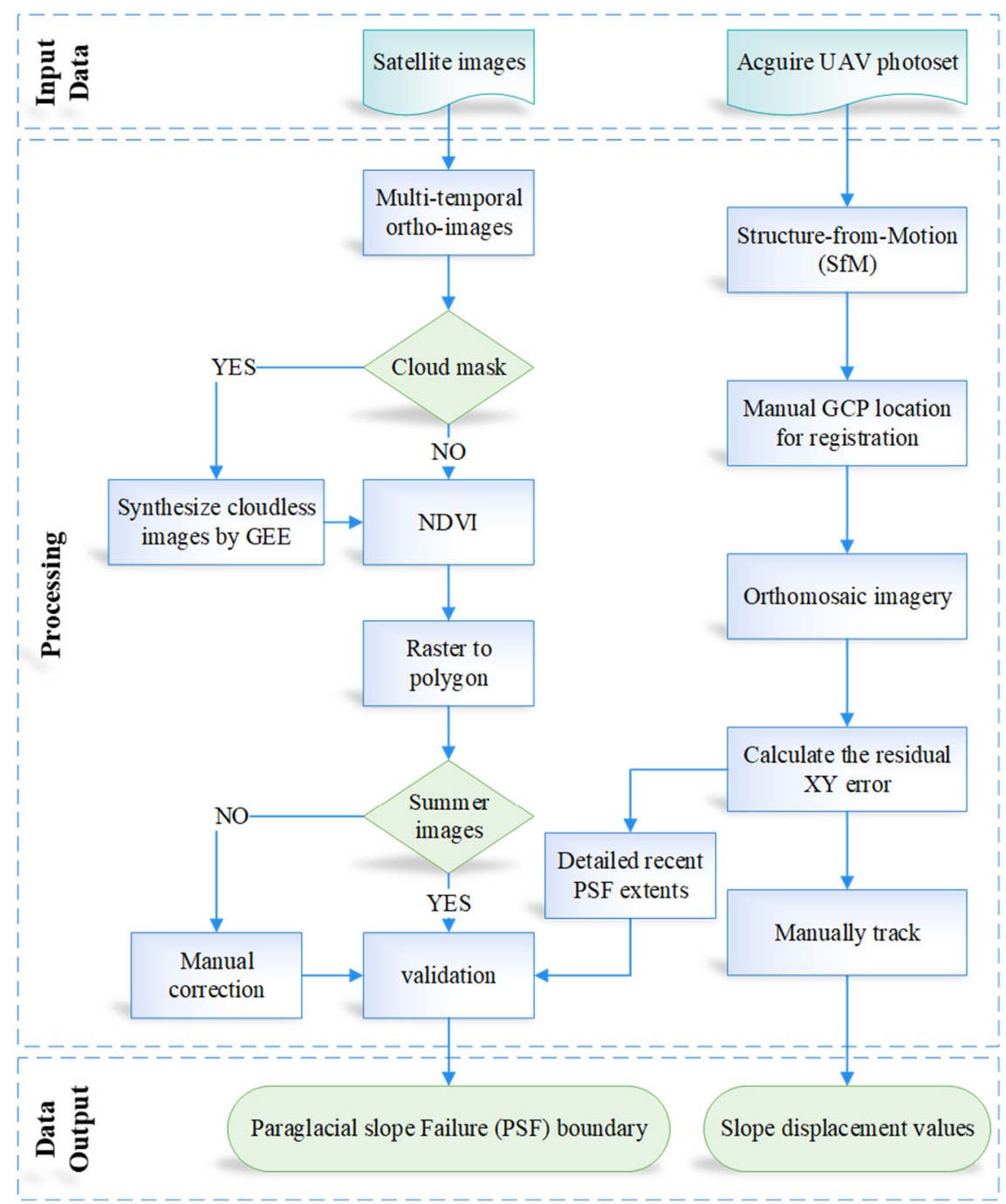

675 Figure 2: Workflow of the methodology followed to mapping the PSFs (changes) and tracking the displacement from multi-temporal image data. 
https://doi.org/10.5194/esurf-2021-18

Preprint. Discussion started: 29 March 2021

(c) Author(s) 2021. CC BY 4.0 License. (a)
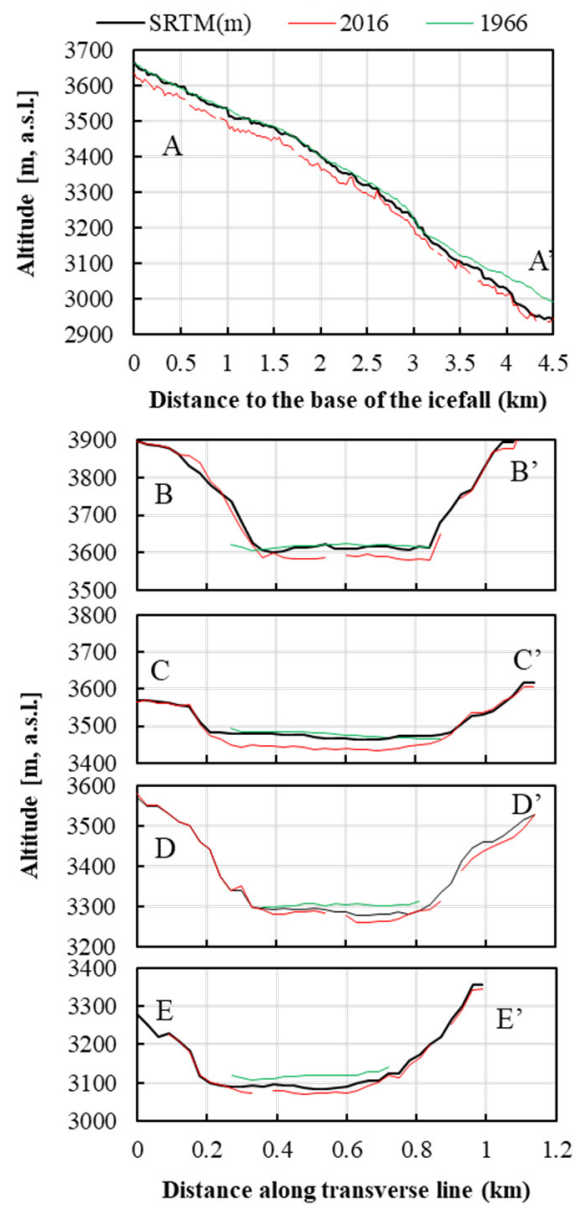

(b)
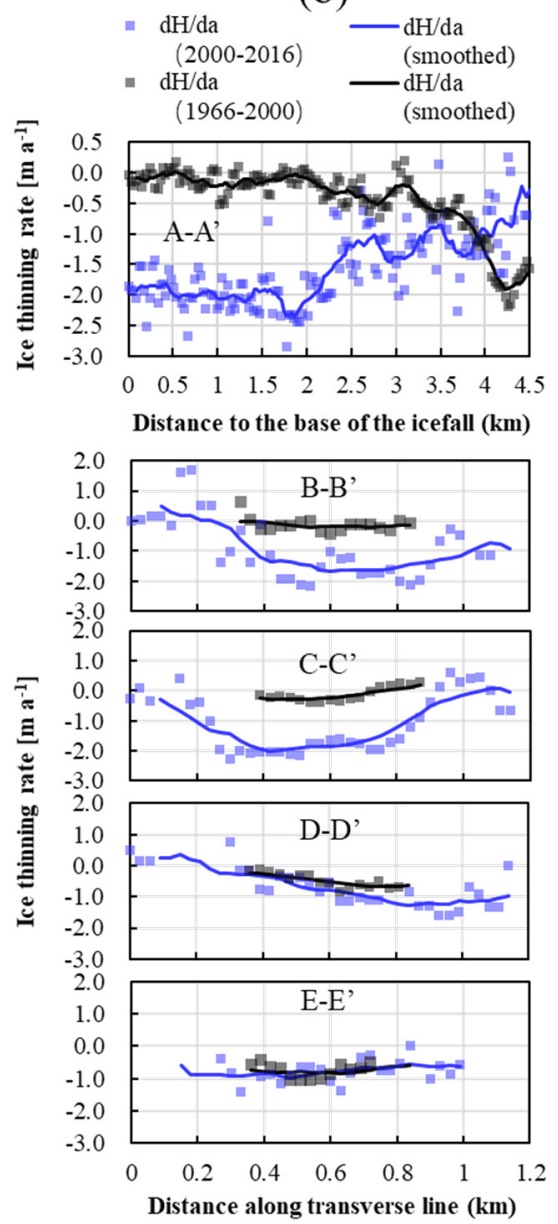

Earth Surface

Dynamics

Discussions (c)
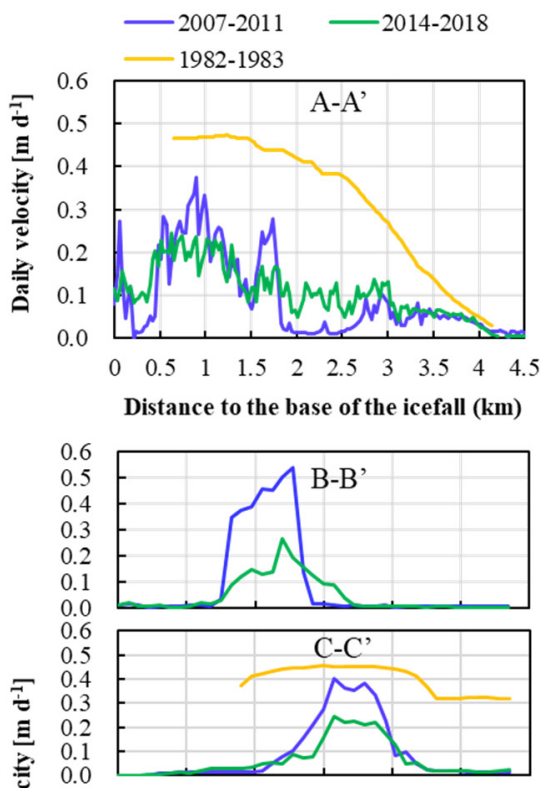

: 0.0

究

今 0.2

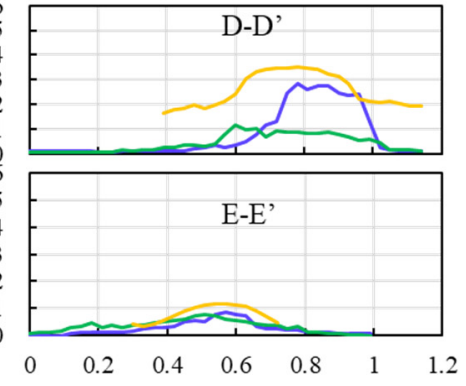

Figure 3: Comparison of ice surface elevations, annual ice thinning rates and velocity changes along profiles A-A' to E-E' in Figure 


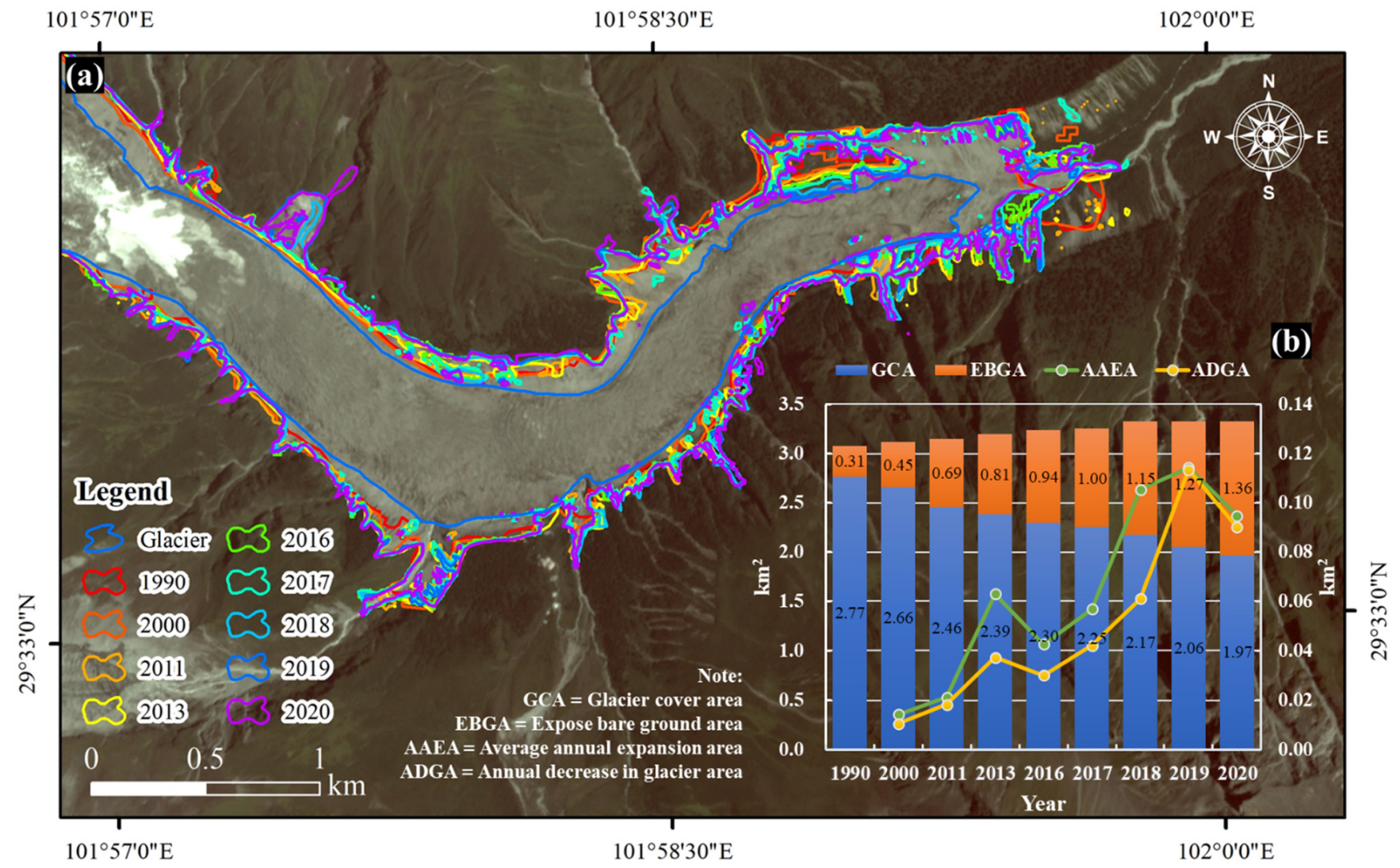

Figure 4: (a) Mapping results of PSFs in the HLG between 1990 and 2020. The glacier boundary (white line) is mapped by a PlanetScope image acquired on August 20, 2020 (background). (b) Changes of the glacier cover area (GCA, blue) and the expose bare ground area (EBGA, orange) between 1990 and 2020. Green line indicates the average annual expansion area (AAEA) of EBGA. Yellow line indicates the annual decrease in glacier area (ADGA). 

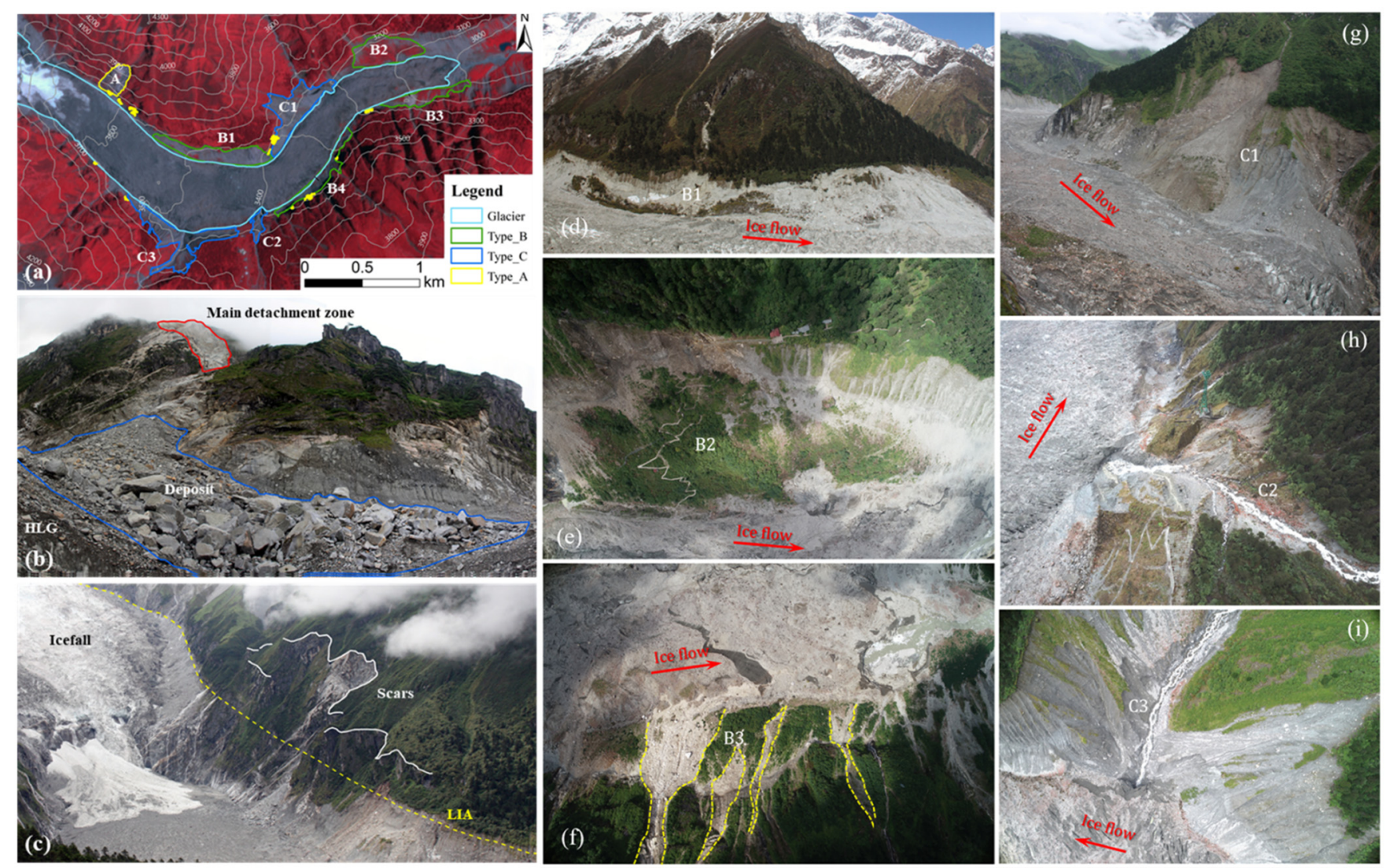

Figure 5: (a) The distribution of three type of PSFs based on Landsat image. (b, c) The particulars of type A failures in the upper part of the HLG's ice tongue. Main detachment zone (red), Deposit (blue). Subplots (d, e, and f) and (g, $h$ and i) are closer photographs of Type B and Type C failures, respectively, field photo by Qiao Liu. 

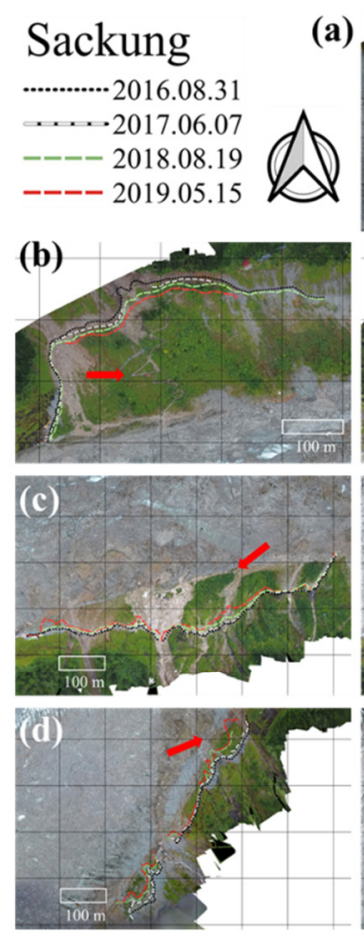

2016-08-31
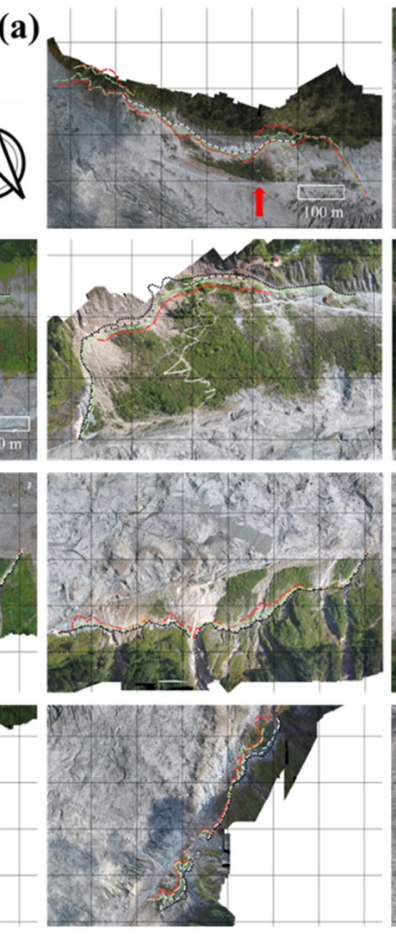

2017-06-07
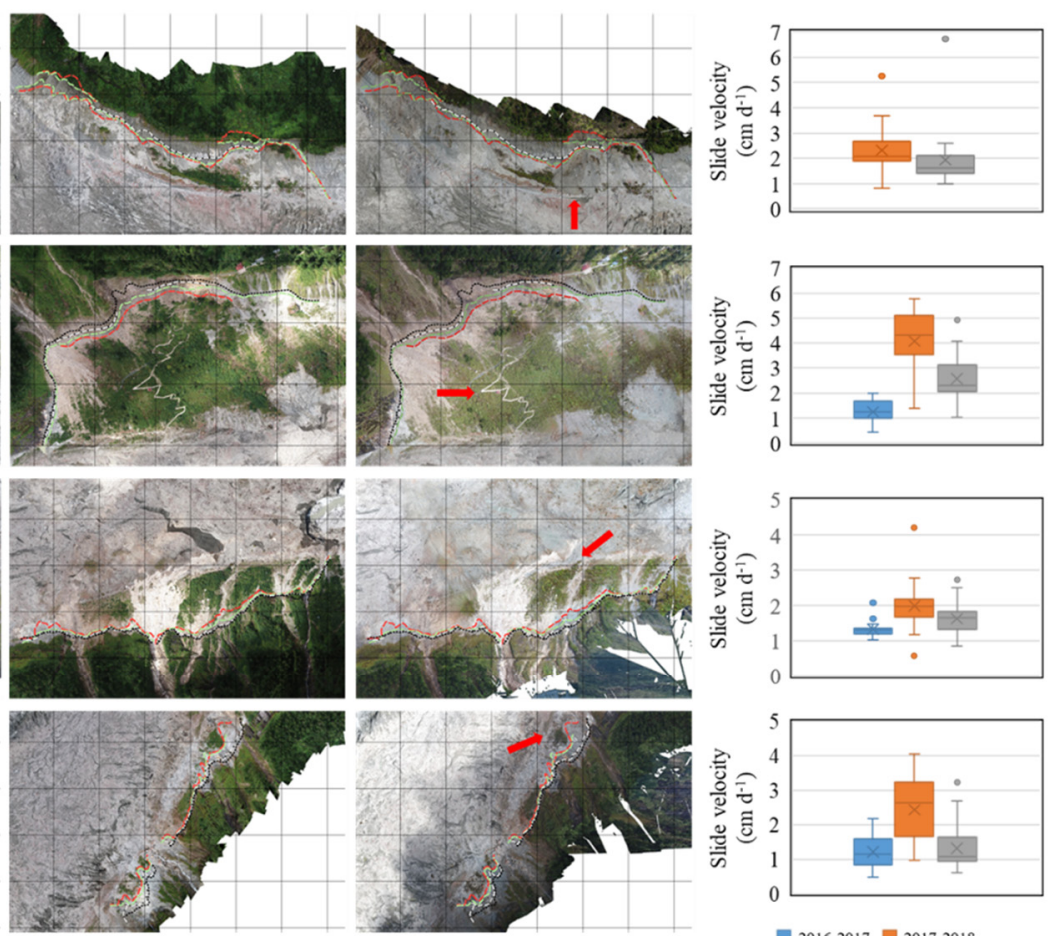

2018-08-19

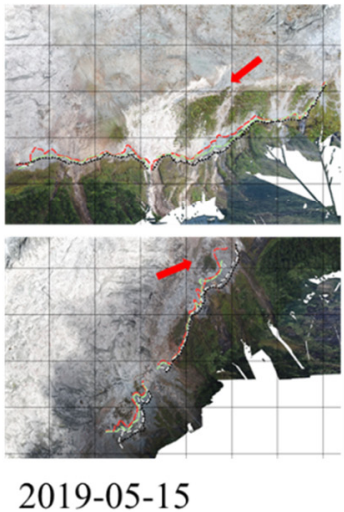

2019-05-15
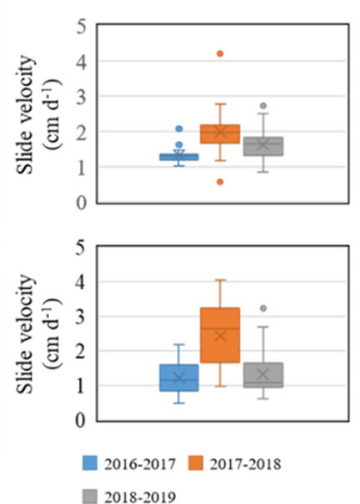

Figure 6: Slopes slides and its velocity of type B. (a) B1, (b) B2, (c) B3, (d) B4 based on UAV images by Qiao Liu et al. 
(a)

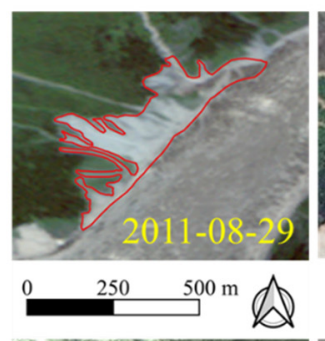

(b)
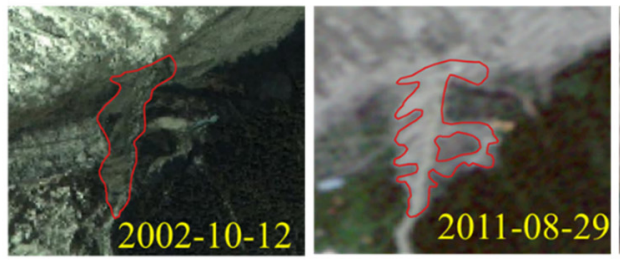
$0 \quad 100 \quad 200 \mathrm{~m}$ \&

(c)
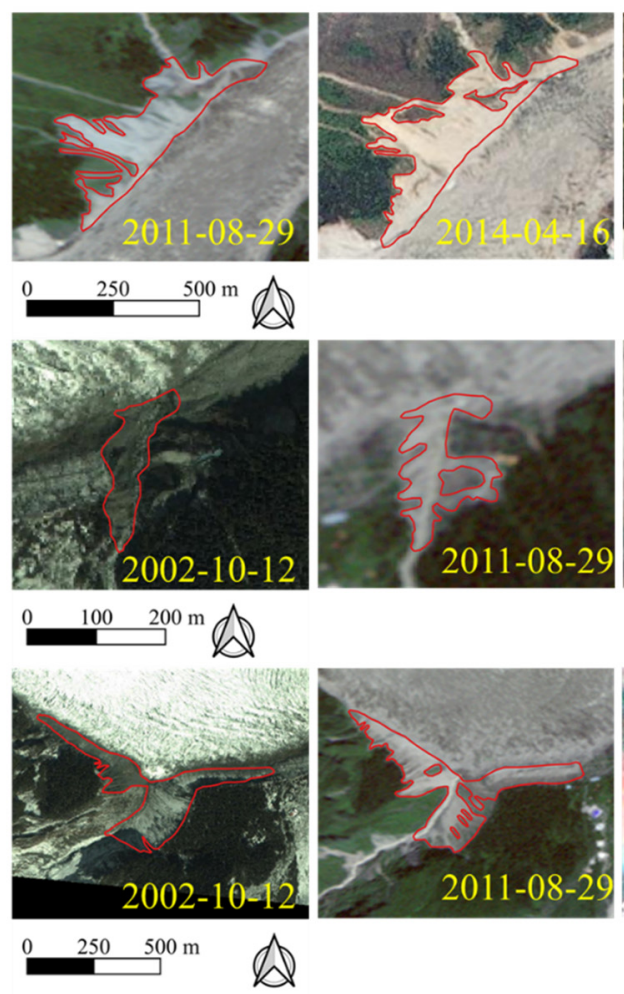
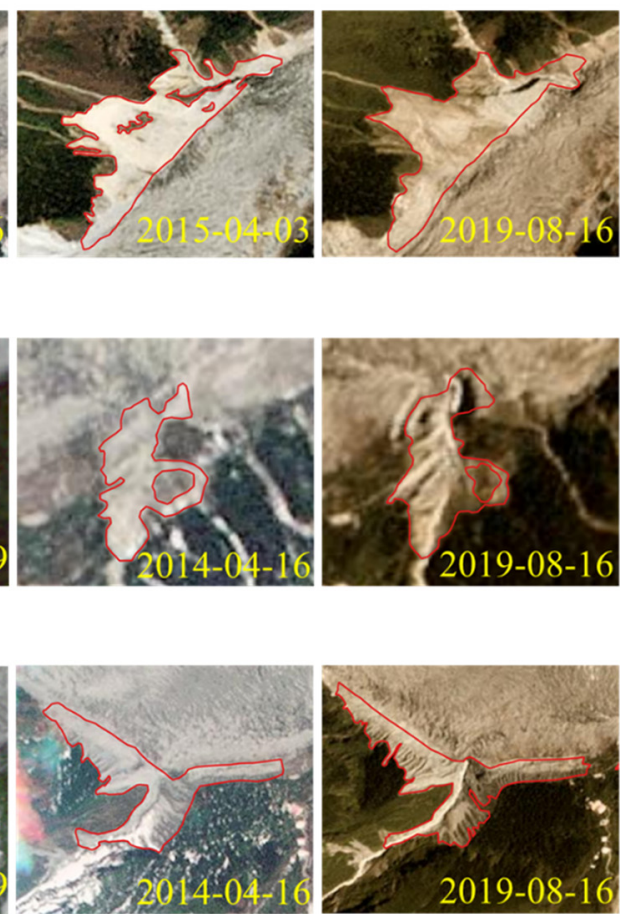

2019-08-16

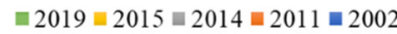

$\mathrm{C} 1$

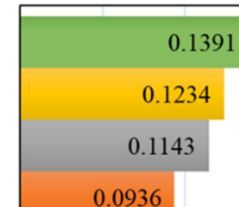

$\mathrm{C} 2$
0.0204
0.0167
0.0123

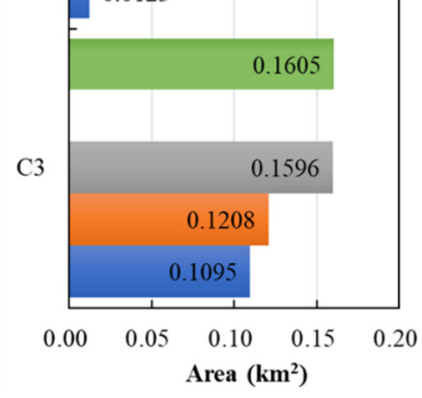

Figure 7: Slopes range and area changes of type C. (a) C1, (b) C2, (c) C3 based on RapidEye, PlanetScope and @ Google Earth (SPOT5) images. 


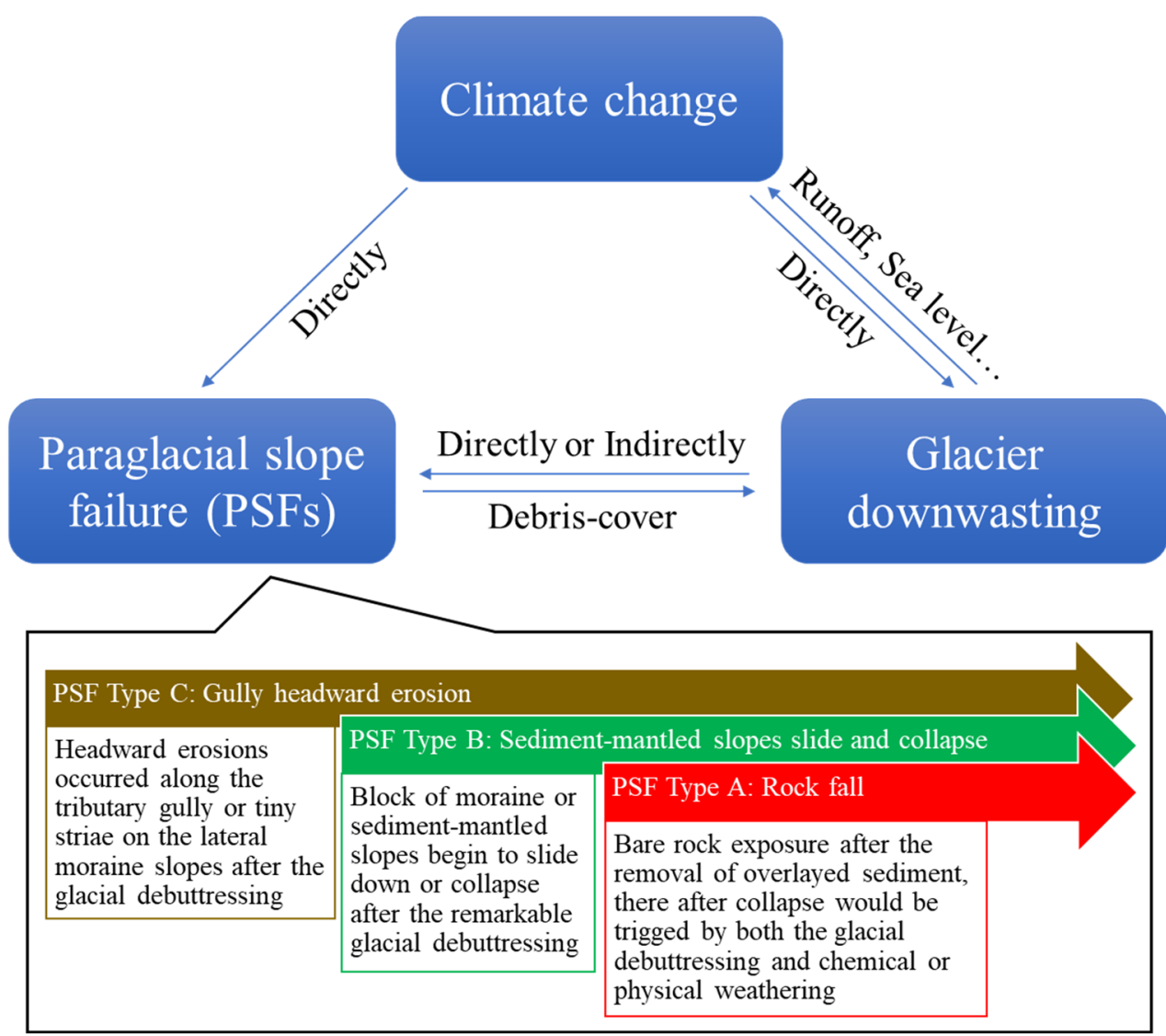

Figure 8: The relationship among PSFs, ongoing climate change, and glacier downwasting. 
https://doi.org/10.5194/esurf-2021-18

Preprint. Discussion started: 29 March 2021

(c) Author(s) 2021. CC BY 4.0 License.

(c) (i)

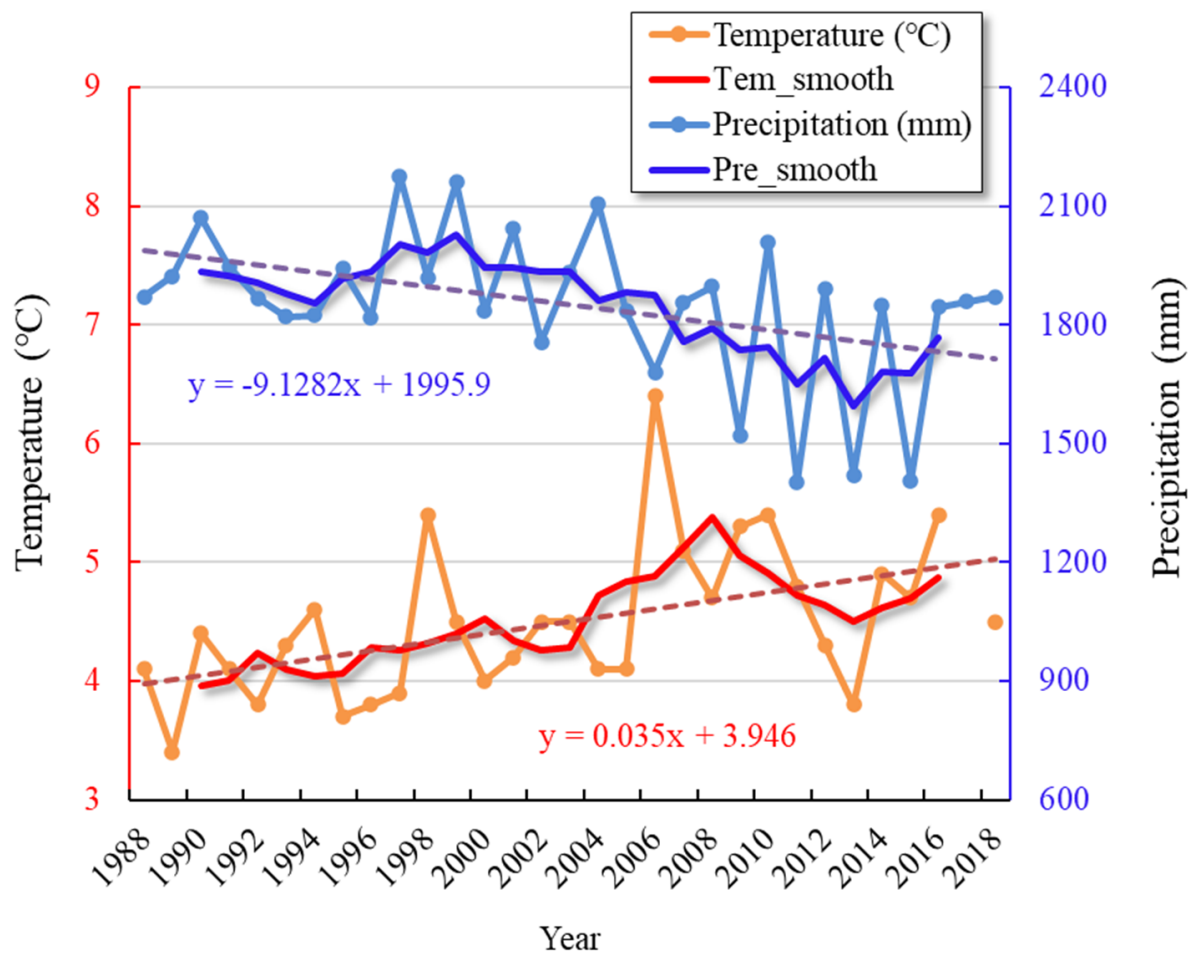

Figure 9: Mean annual air temperature (orange) and annual precipitation (blue) recorded at the $3000 \mathrm{~m}$ station. 
https://doi.org/10.5194/esurf-2021-18

Preprint. Discussion started: 29 March 2021

(c) Author(s) 2021. CC BY 4.0 License.

Table 1: Satellite/UAV data used to map the PSFs extents

\begin{tabular}{llllc}
\hline Sensor Type & Acquiring Date (YYYY.MM.DD) & $\begin{array}{c}\text { Near Infrared } \\
\text { (NIR) }\end{array}$ & Red (R) & Spatial Resolution (m) \\
\hline Landsat TM & $1990.07 .08 / 2000.08 .20$ & Band4 & Band3 & 30 \\
Sentinel 2 & $2016.05 .05 / 2018.08 .23$ & Band8 & Band4 & 10 \\
RapidEye & $2011.08 .29 / 2013.05 .26 / 2014.04 .16 / 2015.04 .03$ & Band5 & Band3 & 5 \\
PlanetScope & $2017.07 .17 / 2019.08 .16 / 2020.08 .20$ & Band4 & Band3 & 3.125 \\
Google Earth & 2002.10 .12 (SPOT5) & Band3 & Band2 & 2.5 \\
DJ-UAV & $2016.08 .31 / 2017.06 .07 / 2018.08 .19 / 2019.05 .15$ & - & - & 0.1 \\
\hline
\end{tabular}

Table 2: Dimensions of PSFs in the study area. We selected periods of high-resolution images with the most obvious terrain changes, the PlanetScope image (2019) for Type A, the UAV images (2016-2019, Fig. S1) for Type B, the PlanetScope, RapidEye, and Google

Earth images $(2002,2011,2014,2015,2019)$ for Type $C$ (locations are shown in Fig. 5a)

\begin{tabular}{cccccc}
\hline PSFs type ID & Length $(\mathrm{m})$ & Width $(\mathrm{m})$ & Area $\left(\mathrm{m}^{2}\right)$ & $\begin{array}{c}\text { Displacement speed / } \\
\text { Upper edge retreat } \\
\text { rate (cm d })^{-1}\end{array}$ & $\begin{array}{c}\text { Increase in exposed } \\
\text { area }\left(\mathbf{m}^{2}\right)\end{array}$ \\
\hline A & 200 & 283 & 47,000 & - & - \\
B1 & 1035 & 114 & 112,424 & $1.96 \pm 0.04 /-$ & $12,125(2016-2019)$ \\
B2 & 644 & 262 & 122,738 & $2.63 \pm 0.04 /-$ & $7,414(2016-2019)$ \\
B3 & 805 & 132 & 63,241 & $1.65 \pm 0.04 /-$ & $8,528(2016-2019)$ \\
B4 & 993 & 103 & 73,270 & $1.66 \pm 0.04 /-$ & $10,130(2016-2019)$ \\
C1 & 849 & 312 & 139,135 & $-/ 3.39$ & $45,499(2011-2019)$ \\
C2 & 164 & 269 & 24,248 & $-/ 0.76$ & $11,923(2002-2019)$ \\
C3 & 1097 & 512 & 160,474 & $-/ 1.15$ & $50,989(2002-2019)$ \\
\hline
\end{tabular}

Table 3: Precipitation data from 2014 to 2018

\begin{tabular}{|c|c|c|c|c|}
\hline Years & $\begin{array}{c}\text { Days } \\
\text { (Precipitation }>0 \mathrm{~mm})\end{array}$ & $\begin{array}{c}\text { Days } \\
\text { (Precipitation }>20 \mathrm{~mm})\end{array}$ & $\begin{array}{c}\text { Days } \\
\text { (Precipitation }>40 \mathrm{~mm})\end{array}$ & $\begin{array}{c}\text { Days } \\
(\text { Precipitation }>60 \mathrm{~mm})\end{array}$ \\
\hline 2014 & 302 & 21 & 0 & 0 \\
\hline 2015 & 245 & 15 & 0 & 0 \\
\hline 2016 & 271 & 25 & 3 & 0 \\
\hline 2017 & 278 & 21 & 1 & 0 \\
\hline 2018 & 269 & 19 & 2 & 1 \\
\hline
\end{tabular}

